This manuscript is a preprint to be submitted for publication in the Journal of the Geological Society. Please note that this manuscript is undergoing peer-review and subsequent versions of the manuscript may have slightly different content. We welcome feedback and invite you to contact the authors directly to comment on the manuscript. 


\title{
1 Strike-slip overprinting of initial co-axial shortening within 2 the toe region of a submarine landslide: a case study from 3 the Angoche Basin, offshore Mozambique.
}

\author{
Clara $\mathrm{Abu}^{1 *}$, Christopher A-L. Jackson ${ }^{1}$, Malcolm Francis ${ }^{2}$ \\ ${ }^{1}$ Basins Research Group (BRG), Department of Earth Science \& Engineering, Imperial College, London, \\ UK \\ ${ }^{2}$ WesternGeco, Schlumberger House, Buckingham Gate, Gatwick, UK \\ *corresponding author: clara.abu07@imperial.ac.uk
}

\section{Abstract}

Submarine landslides (slides) are some of the most voluminous sediment gravity-flows on Earth and they dominate the stratigraphic record of many sedimentary basins. Their general kinematics and internal structure are relatively well-understood. However, how slides increase in volume and internally deform as they evolve, and how these processes relate, in time and space, to the growth of their basal (shear) zone, are poorly understood. We here use three high-resolution 3D seismic surveys from the Angoche Basin, offshore Mozambique to map strain within a shallowly buried, large, and thus seismically well-imaged slide (c. $530 \mathrm{~km}^{3}$ ). We document several key kinematic indicators, including broadly NW-trending lateral margins and longitudinal shears bounding and within the slide body, respectively, and broadly NE-trending symmetric pop-up blocks in the slide toe. Approximately $7 \mathrm{~km}$ downdip of the slide toe wall, thrusts and related folds also occur within otherwise undeformed slope material, with thrusts detaching downwards onto the downslope continuation of the basal shear zone underlying the slide body. Based on the style, trend, and distribution of these features, and their cross-cutting relationships, we propose an emplacement model involving two distinct phases of deformation: (i) bulk shortening, parallel to the overall SEdirected emplacement direction, with contractional shear strains reaching c. 8\%; and (ii) the development of broadly emplacement direction-parallel shear zones that offset the earlier-formed shortening structures. We infer that the contractional strains basinward of the slide body formed due to cryptic basinward propagation of the basal shear zone ahead of and to accommodate updip sliding and shortening associated with, the entire slide mass. Our study demonstrates the value of using 3D seismic reflection data to reveal slide emplacement kinematics, especially the multiphase, non-coaxial nature of deformation, and the dynamics of basal shear zone growth.

\section{Introduction}

Submarine landslides (slides) are subaqueous sediment gravity-driven deposits, emplaced by a 
Weimer 1990; Posamentier and Martinsen 2011). They are commonly sourced from the outer shelf and middle-to-upper slopes of the submarine and lacustrine basin margins or the flanks of salt domes, mud volcanoes, or subaqueous channel margins. Slides are primarily mud-prone, although those sourced from sand-rich shelf-edge deltas may be relatively sand-prone (e.g., Posamentier and Martinsen 2011; Wu et al. 2019). Slope oversteepening, cyclic waves, seismic activity, lowering of wave base, and overpressure development related to fluid expulsion promote slope instability leading to the mass movement (e.g., Masson et al. 2006; Posamentier and Martinsen 2011).

Authors define slides by a tripartite morphology comprising upslope (head), intermediate (translational), and downslope (toe) regions (e.g. Brunsden,1984; Gawthorpe and Clemmey, 1985; Martinsen, 1989; Posamentier and Martinsen 2011; Clare et al. 2019). Extensional strains, which typically manifest as normal faults, dominate the head region. Contractional structures, such as folds and thrusts, are common in the toe region. The toe region can be further sub-divided based on the mode of frontal emplacement (Frey-Martinez et al. 2006); (i) frontally confined slides these are fully buttressed downslope against the downslope toe wall, which results in the development of downslope-verging fold-and-thrust systems that trend normal to the emplacement direction and (ii) frontally emergent slides - these ramp-up above and are associated with material expelled downslope onto the seafloor, beyond the toe wall (Frey-Martinez et al. 2006), and which may be associated with pressure ridges (e.g. Prior et al.1984; Frey-Martinez et al. 2006; Bull et al. 2009). Outcrop datasets provide critical information on the structural style and processes occurring within the toe region of slides, but these are often limited in their areal extent and threedimensionality (Martinsen and Bakken 1990; Van Der Merwe et al. 2011; Ogata et al. 2012; Sobiesiak et al. 2016; Cardona et al. 2020). As such, it can be difficult to put these local observations in their regional context, such as how the observed local contractional strains, and the overall degree of slide confinement, relate to the overall transport direction and size of the host slide. 3D seismic reflection datasets provide this context, revealing the general seismic expression slides and their emplacement kinematics, especially within the toe region. However, only a few 3D seismic reflection-based studies have provided detailed documentation of the along-strike variations in the structural type and evolution of the basal shear surface in this region (i.e. the surface underlying a slide; e.g. Bull et al. 2009; Nugraha et al. 2020; Couvin et al. 2020). Related to this, intra-slide strain has also only rarely been quantitatively investigated using 3D seismic reflection data (e.g. Steventon et al. 2019; Bull and Cartwright 2020). As a result, we have a relatively poor understanding of the detailed processes occurring within the toe region of submarine slides and related to this, how slides increase in volume via basal shear surface propagation (Martel, 2004; Hodgson et al. 2019).

The translational zone of slides is often thought to be dominated by pure horizontal translation, with little internal deformation. However, along-strike variations in the rate of downslope translation of a failed sediment mass can lead to the formation of flow cells, separated by regions of discrete (i.e. strike-slip faults) or diffuse (i.e. shear zones) deformation (Steventon et al. 2019; Nugraha et al. 2020). Such cells have been documented in the field at the $\mathrm{cm}$ to $\mathrm{m}$-scale (Alsop and Marco 2014). However, it is often not explicitly clear how they relate to the overall kinematics of the deposit that hosts them, or where or when they formed within the failed mass (Farrell 1984; Alsop and Marco 2014). 3D seismic reflection data can help fill these gaps in our knowledge, showing that flow cells form within the translational zone in response to variations in the 
downslope translation speed of and/or total strain within, the failed sediment mass (Gee et al. 2005; Bull et al. 2009; Steventon et al. 2019).

Here we use high-resolution, 3D, time-migrated seismic reflection data to undertake detailed mapping and strain analysis of a shallowly buried, large, and thus well-imaged submarine landslide (c. $530 \mathrm{~km}^{3}$ ). The 3D seismic reflection dataset fully covers the toe region of the deposit, which therefore forms the focus of this study. The key objectives are: (i) to identify and map structural features within the slide to determine its overall emplacement direction and internal kinematics; (ii) to identify distinct phases of deformation within the slide toe; (iii) to investigate along-strike variation in the structural style and evolution of the basal shear surface in the toe region; and (iv) to propose a model for the growth of the basal shear zones of slides.

\section{Geological Setting}

The offshore basins in Mozambique initially formed during the early Mesozoic in response to the break-up of Gondwana (Mahanjane 2014). The Angoche Basin (Fig. 1) is south of the Rovuma Basin, bound to the west by the Mozambique continental margin and east by the Davie Fracture Zone. Rifting occurred in two key stages; (i) Middle Jurassic (Bajocian-Bathonian, 170-166 Ma) and (ii) Late Jurassic (154 Ma) in response to north-south directed extension (Reeves and Mahanjane 2013).

The study area is located in a shelf-to-slope setting, in an up to c. $4.5 \mathrm{~s}$ (TWT) sedimentary sequence capping crystalline basement. Synrift lacustrine deposits of the Makarawe Formation deposited during the Middle Jurassic (Bajocian), overlain by Uppermost Jurassic post-rift marine shales and siltstones that show shallow-marine conditions (Sapri et al. 2013). Deeper-water and related deposits characterise Cretaceous succession (Francis et al. 2013; Mahanjane and Frank 2014). The Cretaceous contains channels, fans, and finer-grained slope deposits (Fig. 2). Relatively confined slope channels became increasingly common during the Paleogene, reflecting overall progradation of the margin. Post-Eocene uplift of East Africa resulted in an increased sediment flux into the basin, and the deposition of increasingly sand-rich, deep-water channels and fans (Salman and Abdula 1995). Uplift also steepened the shelf and slope, and it was this, in combination with increased seismicity, that destabilised the basin margin (Jacques et al., 2006), leading to the emplacement of thick, extensive, submarine slides. One of these slides forms the focus of this study (Fig. 3).

\section{Dataset and methods}

The data used in this study consist of three 3D seismic surveys; two broadband time-migrated (PSTM) seismic reflection datasets that cover areas of c. $15,041 \mathrm{~km}^{2}$ and c. $4765 \mathrm{~km}^{2}$, and a depthmigrated volume that covers $2545 \mathrm{~km}^{2}$. The time-migrated datasets are processed differently, with the more extensive survey having an inline spacing of $12.5 \mathrm{~m}$ and crossline spacing of $25 \mathrm{~m}$. We used this data volume to define the overall geometry and kinematics of the studied slide. The smaller survey has an inline spacing of $6.25 \mathrm{~m}$ and crossline spacing of $12.5 \mathrm{~m}$. This volume we used for a detailed analysis of the slide toe. The dominant frequency of the data varies with depth but is c. $60 \mathrm{~Hz}$ in the interval of interest. We took depth interval velocities for the sediment from models updated by advanced full-waveform inversion (FWI) and common image point (CIP) 
tomography. From this we derive an average seismic velocity of $1935 \mathrm{~ms}^{-1}$, giving a maximum estimated vertical resolution of c. $8 \mathrm{~m}$ (wavelength $\lambda=\mathrm{V} / \mathrm{f}, \mathrm{m}$; maximum vertical resolution $=\lambda / 4$; Sheriff and Geldart 1983), and a horizontal resolution of c. $32 \mathrm{~m}$. The data are SEG standard polarity with an increase in acoustic impedance represented by a peak (blue) and a decrease by a trough (red).

We focus on a well-imaged slide located $620 \mathrm{~ms}$ to $3637 \mathrm{~ms}$ (c. 599-3483 m, using average slide interval velocities of $1935 \mathrm{~ms}^{-1}$ ) beneath the seabed (Fig. 3). Water depths increases from $0.45 \mathrm{~s}$ $(336 \mathrm{~m})$ in the northwest to $>3 \mathrm{~s}(2242 \mathrm{~m})$ in the southeast. We mapped the top and base of the slide to constrain its structural style and infer its emplacement kinematics. We created isoproportional horizons (see Zeng et al. 1998) between the slide top and base to reveal its internal structural style, from which we infer its emplacement kinematics (see below).

Several seismic attributes reveal the internal and external geometry of the studied slide: (i) the variance attribute - isolates edges and discontinuities in the horizontal continuity of amplitude, and hence accentuates structural features (e.g. faults) within the slide (Van Bemmel et al., 2000); the variance attribute is used as an input to the ant-tracking workflow; (ii) ant-tracking performs edge enhancement (or skeletonization) of the data, and we use it for identifying faults and other linear anomalies (e.g. shear zones) within the seismic data (Pedersen et al., 2002); (iii) eXchroma allows a simultaneous rendering of several slices or layers in continuous RGB colours, with the method adapted from the processing of satellite images for geology (Laake, 2015). In our case, image processing enhances the contrast of the RGB images to reveal the slides internal geometry; (iv) dip illumination estimates the cross-correlation dip to reveal structural discontinuities (e.g. faults) in the seismic data and image the rugosity of a mapped seismic horizon; (v) root mean square $(R M S)$ measures the reflectivity or energy in a dataset, and we use it to map reflective megaclasts contained within the overall lower-amplitude, debritic matrix of the slide (e.g. OrtizKarpf et al. 2017); (vi) amplitude contrast computes amplitude derivatives between neighbouring traces, followed by a normalization of the calculated differences. Surface-based amplitude extractions involved windowed extractions above, below, or on specific horizons. Iso-slicing allows us to examine the internal structural style and assess the kinematics of the slide.

\section{Shortening-related strain analysis}

We use the Dynel software to calculate shortening and investigate longitudinal strain within the toe region. Dynel software is built on mechanics-based restoration techniques involving conservation of mass, conservation of linear and angular momentum, and constitutive equations relating stress to strain, or stress to deformation rate. We take an individual layer and build a mesh characterised by material elastic properties, including Young's modulus and Poisson's ratio. The layer is restored to a target paleosurface, with built-in vectors of displacement resulting in a restored state. We ran the software on a representative depth-migrated seismic line that trends NW within the toe region and that has a good preservation of internal reflections. The line is almost perpendicular to the trend of the shortening structures characterising this region (see below). We interpret an intra-slide horizon (H1) to constrain the extent of horizontal shortening. This was dependent on identifying kinematic indicators using a combination of time-structure and attribute 
maps, and seismic sections. The shortening values of the pre-kinematic strata of the fold and thrust systems are estimated by comparing the present bed length (L) with the original bed length of the pre-kinematic horizon (Lo): e $=($ Lo-L) $/ \mathrm{L}$.

\section{General seismic expression of the slide}

We begin by providing a general description of the studied slide using the larger, time-migrated seismic dataset; in contrast to the depth-migrated seismic dataset, which provides good imaging of the slides toe region, the time-migrated images the slides headwall and lateral margins, and the full range of its contained seismic facies.

\subsection{Basal, lateral, and upper contacts}

The slide has a maximum depositional length of c. $85 \mathrm{~km}$ (Figs. 3 \& 4), an area of $3746 \mathrm{~km}^{2}$, a maximum thickness of c. $447 \mathrm{~ms}(380 \mathrm{~m})$ (Fig. 5), and a total volume of c. $530 \mathrm{~km}^{3}$. It is c. $46 \mathrm{~km}$ wide in its central part and narrows downdip to c. $26 \mathrm{~km}$ in its toe region. Low-amplitude, chaotic seismic reflections dominate the slide, that overly a high-amplitude reflection that is broadly concordant with underlying stratigraphy (Figs. 4, 6b-d). We interpret the high-amplitude basal reflection as a basal shear surface or zone across which the slide translated (e.g. Frey Martinez et al. 2005; Bull et al. 2009; Wu et al. 2021). The basal shear surface passes upslope into a headwall scarp zone that defines the up-dip limit of the slide, and downslope into a frontal ramp that defines its downdip limit. The basal shear surface steps up through stratigraphy to define the slides lateral margins; beneath the slide, the basal shear surface comprises several ramps (Fig. 4). The basal shear surface is generally defined by a relatively continuous, negative polarity (i.e., trough) reflection, although it becomes locally discontinuous near ramps, where it is discordant to underlying stratigraphy.

The slide terminates across-strike against a lateral margin (Figs 4b-c, 5) that trends parallel to the gross, SE-directed emplacement direction. The lateral margin is easy to trace downslope, defined by a clear, straight, steep, continuous scarp that is up to $300 \mathrm{~ms}$ high and ultimately links to the frontal ramp in the toe region (Fig. 5b). En echelon tension cracks locally flank the lateral margin, such as in the NW part of the toe region (Fig. 5b).

The top of the slide is rugose and has a vertical relief of up to $989 \mathrm{~ms}(957 \mathrm{~m})$, measured from the landward part of the survey to its frontal margin in the toe region. The slide is thickest and has the most significant relief in the SW, where thrusts and thrust-bound pop-up blocks are common and form positive relief along the slides top surface (Figs. 4a \& 7). In addition, chaotic seismic facies fill the depressions between thrust-cored folds and shear zones near the slide toe.

\subsection{Internal seismic facies}

The slide's internal seismic expression and structural style are highly variable, and we lack well data to directly calibrate its composition and sedimentological facies. Because of this, we develop a seismic facies classification scheme drawing on the results of other shallowly buried, undrilled slides that are well-imaged in 3D seismic reflection data (see references below), and more deeply buried slides that have been drilled and for which lithological data are thus available (Wu et al. 2021). 
We define three seismic facies based on the changes in the internal configuration of the reflections, in cross-section and map-view (Fig. 6b-d): (i) SF1 - very low-amplitude, chaotic reflections, inferred to be the slides debritic matrix (e.g. Posamentier and Kolla 2003; Posamentier and Martinsen 2011; Olafiranye et al. 2013; Alves et al. 2014; Ortiz-Karpf et al. 2017; Nugraha et al. 2019); (ii) SF2 - reflections of variable reflectivity, folded and offset by thrusts (e.g. Bull et al. 2009; McGilvery et al., 2004; Frey-Martinez et al. 2005; 2006; Alfaro \& Holz, 2014), interpreted as imbricate thrust and fold systems, and (iii) SF3 - high-amplitude, isolated blocks of coherent, parallel, weakly-to-moderately folded reflections set within an inferred debritic matrix (e.g. SF1) as megaclasts (e.g. McGilvery et al. 2004; Bull et al. 2009; Frey-Martinez 2010; Jackson 2011; Posamentier and Martinsen 2011; Olafiranye et al. 2013; Ortiz-Karpf et al. 2015; Alves 2015). As we will discuss below, style and distribution of the thrust-and-fold systems (SF2) in the slide's toe region, as well as their cross-cutting and temporal relationship to other structure features, is important for determining the slides emplacement kinematics.

\section{Structural characteristics of the toe region}

Having provided a general overview of the external form, and internal seismic facies of the slide, we now focus on the geometry of the basal shear surface and structural style of related structures in the toe region.

\subsection{Basal Shear surface}

The basal shear surface deepens basinward, before steepening upwards in the toe region to define the frontal ramp and the downdip limit of the contractional region (Fig. 8). The frontal ramp trends broadly perpendicular to the gross, SE-directed transport direction of the slide and has a complex morphology (Fig. 8). In the SE, the basal shear surface is defined by a c. 230 ms-high frontal ramp, deepest immediately adjacent to the frontal margin (Fig. 8). To the NE, however, the frontal ramp has a more complex, staircase-like geometry, consisting of two steep-dipping ramps separated by an intermediate, strata-parallel detachment (Figs. 8a-b). There is considerable variation in relief (up to $450 \mathrm{~ms}$ ) along the basal shear surface due to the presence of these ramps (Fig. 5a). Slide material covers the ramps in the NE, the SE and extends basinward onto the protoseafloor, beyond the most distal ramp (Fig. 7). Thus the slide falls into the frontally emergent termination style (sensu Frey-Martínez et al. 2006).

\subsection{Internal body}

\subsubsection{Shortening-related structures}

General description. A range of shortening-related structures strongly deforms the contractional domain, and especially the most distal part of the toe region (Figs. 7b, 8 and 9). Thrust-bound popup structures are particularly common, occurring in arcuate belts that trend broadly northeast. The bounding thrusts can be defined as either forethrusts (i.e. N-dipping) or back-thrusts (i.e. Sdipping), and they have an average throw and dip of c. $60 \mathrm{~m}$ and c. $40-50^{\circ}$ (some up to $>55^{\circ}$ ), respectively. The spacings between thrust pairs (measured from crest to crest of the pop-up blocks) range from 460 to $805 \mathrm{~m}$, with the thrust height being $150-200 \mathrm{~m}$ and detaching downwards onto the basal shear surface (Fig. 4a). Folds within thrust-bound pop-ups are gentle, non-cylindrical, and affect sections as thick as $370 \mathrm{~ms}$. The fold axes, like their bounding thrusts, largely trend NE. 
The overall E-to-NE strike of the thrusts and related folds suggest an overall slide transport direction to the SE. Our analysis of the present and restored lengths of $\mathrm{H} 1$ of $12.39 \mathrm{~km}$ and 13.43 $\mathrm{km}$, respectively, suggests contractional shear strains (as expressed and accommodated by seismically imaged thrusts) of c. $8 \%$. This reflects the minimum distance travelled by the slide, at least in its toe region (Frey-Martínez et al. 2006).

The toe region is divided in two parts: an inner thrust-belt and an outer thrust-belt (Fig. 8c). The inner thrust-belt is dominated by symmetrical, thrust-bound pop-up blocks, within which internal reflections are relatively well-preserved (Fig. 8c). These internal reflections are similar in terms of overall seismic character to adjacent, undeformed strata located outside the slide body (Fig. 10c). The outer thrust-belt is characterized by so-called pressure ridges (sensu Bull et al. 2009) that are most evident in the SE part of the toe region (Figs. 8c, 9). Pressure ridges are inferred to be an expression of sub-seismic thrusts (Bull et al. 2009). These ridges are linear (convex-downslope) in plan-view and trend perpendicular to the overall south-easterly emplacement direction (Fig. 8c). Contractional strains are also developed c. $7 \mathrm{~km}$ downslope of the existing toe wall (Figs. $10 \&$ 11). Critically, the related structures are geometrically similar (but simply less numerous) than those within the main slide mass, detaching downwards onto the downslope continuation of the basal shear surface or zone underlying the slide body (Fig. 10).

Quantification of along-strike strain variability and thrust growth. We follow the method outlined by Nugraha et al. (2020) to illustrate how strain can vary along-strike in the toe region of a slide and, more specifically, to infer how thrusts bounding pop-up blocks grew in response to progressive shortening. We focus on one particularly well-imaged set of broadly NNE-SSWstriking fore- (i.e., WNW-dipping) and back-thrusts (i.e., ESE-dipping) that bound the tenth block (PB10) north-westwards of the slide's frontal margin (Fig. 12). We chose these structures because they and an intra-slide marker reflection (H1; Fig. 12) they offset (see below), can be mapped over a relatively long distance $(\mathrm{c} .7 \mathrm{~km}$ ) along-strike. We measure throw (i.e., the vertical component of displacement) of the intra-slide marker reflection (H1; Fig. 12) every $125 \mathrm{~m}$ along-strike on seismic profiles trending normal (i.e., broadly NW) to fault strike (i.e., broadly NNE). Throw is plotted against along-strike distance to create throw vs. distance (T-x) profiles, parallel to fault strike. Following Nugraha et al. (2020), we are looking for the following specific structural configurations: (i) local throw maxima, which may indicate the positions of thrust nucleation; (ii) local throw minima, which may define areas where thrust have geometrically (i.e., hard) or kinematically (i.e., soft) linked.

Seismic sections across PB10 illustrate how its geometry changes along strike from the SE to the NE (Fig. 12e-f). In the SE, it is defined by a single pop-up block bound by forethrust FT1 and backthrust BT1 (Fig. 12f), passing along-strike to the NE into two pop-up blocks bounded by two forethrusts (FT2 and FT3) and two backthrusts (BT2 and BT3) (Fig. 12g).

Ideal T-x profiles display maximum throws near the center of a fault with a progressive taper of the separation to zero at the fault tips. For this study, throw is measured at the best imaged parts of the faults, mostly in the central part and areas of maximum throws. Maximum throw on FT1 ranges from c. $40-45 \mathrm{~m}$ in the SE to c. 60- $65 \mathrm{~m}$ in the NE. The T-x profiles for the pop-up bounding thrusts highlights a coherent geometric pattern of cumulative throws across the 
combined segments (Fig. 12d). For example, the profile for FT1 tips out at c. $4300 \mathrm{~m}$ along-strike where it is hard-linked to FT2 and FT3. A local minimum in the cumulative throw profile of the forethrusts corresponds to fault tip overlap for FT2 and FT3. The throws on these faults (i.e., FT2 and FT3) subsequently increase progressively to the NE of the analysed pop-up block. We note that there is no major change in throw across the shear zones offsetting the thrusts. The T-x plot for BT1 shows a similar overall throw profile or pattern to FT1.

Interpretation. We interpret that toe thrusts within the toe region formed in response to the growth and linkage of multiple smaller segments, with regions of thrust nucleation recorded by throw maxima and zones of linkage defined by subtle throw minima. The fact that throw does not noticeably change across them, confirms our interpretation that the magnitude of offset across the shearing-related structures (note pink dotted lines on Fig. 12a-b) is minor (i.e., c. $60 \mathrm{~m}$; see below), i.e., offset across shearing-related structures was not sufficient to passively juxtapose throw profiles with strongly differing throws.

\subsubsection{Shearing-related structures}

Several downslope-trending lineaments occur within the toe region of the slide. The shear zones have a range of orientations and crosscut and offset the thrust-bound pop-up blocks described above (see dotted lines on Fig. 7). The shear zones crosscut the entire thickness (i.e. up to $400 \mathrm{~ms}$ $(387 \mathrm{~m})$ ) of the slide deposit. Shear zones can sometimes be clearly expressed on the top surface of submarine slides (Masson et al. 1993; Gee et al. 2006). However, in our case, we suggest the shear zone, which is likely filled with chaotic, sheared, seismically chaotic material, extends into and deforms debritic material that is itself poorly stratified and thus seismically chaotic. As such, the shear zone expression in the capping debrite is rather subtle. The shear zones are very narrow (up to $100 \mathrm{~m}$ wide) zones defined by chaotic seismic facies, that might derive from the overriding debrite (Fig. 10). We identify three main groups of shear zones based on their orientation: slopeparallel 'longitudinal' (NW-SE), slope-oblique 'sub-orthogonal' (N-S) and slope orthogonal (NNE-SSW) (Fig. 7). Orthogonal shear zones are smaller and common downslope in the toe region, whereas the slope-parallel and oblique shears are longer. Longitudinal shears separate Areas A and B. These shears are narrow (c. 90 - $120 \mathrm{~m}$-wide) and extend for c. $12 \mathrm{~km}$ (see Fig. $9)$. There is a slight change in the top surface relief between the two areas, with a vertical difference of 4-6 m. Sub-orthogonal shears separate area B from area C; these structures are narrow (c. 60 $90 \mathrm{~m}$-wide) and extend for c. $21.5 \mathrm{~km}$. One of the shear zones described above trends oblique to, crosscuts, and offsets the pop-up and bounding thrusts in the SE, demonstrating sinistral offset c. $60 \mathrm{~m}$ of the presumably older, shortening-related structure (Fig. 12b).

\section{Interpretation and Discussion}

\section{Emplacement mechanisms}

Having described the seismic expression and structure of the slide, we now consider the processes involved in its emplacement. First, we note that the slide is overlain by a chaotic seismicstratigraphic package interpreted as a debrite (e.g., SF1; Fig. 6b). This stratigraphic relationship suggests three potential end-member scenarios for the evolution of the slide: (1) the passage of the overlying debrite initiated failure and deformation of the underlying substrate (e.g. Hodgson et al. 2019), (2) slope failure and slide formation produced the development of an overlying debris flow 
(3) supra-slide relief was later passively filled by a possibly much younger, genetically unrelated debrite. We now more fully describe and evaluate these models.

Scenario 1 envisages that the passage of an overriding debris flow generated slope failure, which caused the critical shear stress of the substrate to be exceeded, and the propagation and growth of the basal shear surface along subsurface bedding planes (Watt et al. 2012). Such a causal link between debrite emplacement is inferred from 3D seismic reflection (e.g. Moscardelli et al. 2006; Hodgson et al. 2019), and from field data from the Karoo Basin, South Africa (Van der Merwe et al. 2011). For example, Van der Merwe et al. (2009) argue for substrate deformation and slide initiation due to high basal shear stresses and vertical loading stress exerted by an over-riding debris flow. The relatively thick $(10-70 \mathrm{~m})$, areally extensive (c. $\left.3000 \mathrm{~km}^{2}\right)$ slide, which was not transported a substantial distance downdip (see their Fig. 11), essentially formed part of a basal shear zone (rather than the slide being bound below by a discrete basal shear surface; e.g. Butler et al., 2010; Wu et al., 2021). Their observations suggest that debris flow-driven shear coupling might explain the development of thick, extensive slides that undergo only limited horizontal translation (Schnellmann et al. 2005; Minisini et al. 2007; Dasgupta 2008). The following observations broadly support scenario 1: (i) the slide is capped by a debrite that has the same mapview extent as the slide itself (Figs. 8b-c); (ii) there is no evidence for strong, erosional scouring (e.g., grooves) at the base of the slide, suggesting it has only translated a short distance; and (iii) thrust-cored folds in the distal region are capped by but are not eroded into (at least not the resolution afforded by the seismic reflection data) by the overlying debrite (Fig. 6c).

Despite these observations being broadly supportive of scenario 1, we note that the slide has a total volume of c. $530 \mathrm{~km}^{3}$, with the thickness ratio between the relatively thick slide (c. $300 \mathrm{~ms}$ ) and relatively thin debrite (80-100 ms) being relatively large (i.e. c. 3:1). It is not clear, therefore, if a relatively thin debris flow could cause sufficient substrate loading to generate such a volumetrically significant failure along a deep-lying bedding plane (see also discussion by Steventon et al., 2019).

Scenario 2, like Scenario 1, also views the slide and debrite as being genetically related, although, in this case, the formation of the slide causes the debris flow, not the other way around. More specifically, having formed in response to slope failure, the upper part of the slide ingests water, becomes more dilute, and transforms into a debris flow (Sammartini et al. 2021). Both the slide and the debris flow travel downslope, with the former ploughing into and incorporating the material ahead of it, forming folds and thrusts (Figs. 7, 8b-c, 9, 10 and 13). The following observations support scenario 2: (i) the presence of intra-slide megaclasts (SF3), which are suggestive of seabed erosion and entrainment during slide emplacement (e.g., Alves, 2015) (Fig. 10); and (ii) regularly spaced, thrust-bound pop-up blocks in the toe region. Sammartini et al. (2021) proposed a similar model, for the Zinnen Slide in Lake Lucerne, Switzerland, in which debrite and slide emplacement are considered coeval. They suggest the initiation and growth of shear bands along discrete decollements on steep slopes was associated with the basinward propagation of deformation. Thus, the landslide evolves as two rheologically separate but genetically related bodies; a relatively dilute debrite, and a more cohesive slide that ploughs into basin-plain sediments, forming a fold-and-thrust belt. 
Scenario 3 envisages that the slide and debrite are genetically unrelated, with relief along the top of the former being filled, possibly in association with some erosion, by the latter. Joanne et al. (2013) describe this stratigraphic relationship at the Matakaoa continental margin, northeast New Zealand. The authors report that a debritic mass flow eroded fold-and-thrusts developed in an underlying slide: manifesting in the formation of grooves and truncated basin reflections. We do not observe this erosion between the debrite and the slide (at least not the resolution afforded by the seismic reflection data). Scenario 2 seems to be most plausible for this slide based on our observations from the seismic dataset that imply the landslide evolved as a single event that propagated downslope as two rheologically separate bodies.

\section{Basal shear surface evolution}

The development of a basal shear surface or zone is a common process to all three scenarios proposed above. Such surfaces or zones can, for example, occur along pre-existing planes of weakness (e.g. bedding surfaces) or along or just below overpressure-weakened, clay-rich intervals (e.g. Bryn et al. 2005; Frey Martinez et al. 2006; Sammartini et al. 2021). In seismic reflection data, the basal shear surface or zone is often a distinctive, commonly high-amplitude seismic reflection, concordant to or strongly discordant with underlying stratigraphy (Bull et al. 2009; Steventon et al. 2019; Nugraha et al. 2020). Although mappable over large areas, the mechanisms responsible for growth of the basal shear surface or zone during slide evolution are poorly understood.

Our data allow us to propose a model for how the basal shear surface or zone developed in our specific case, with this model potentially applicable to other slides. Here we consider a simple mechanical explanation proposed by Martel (2004) for subaerial (rather than subaqueous) landslides. In this model, we view the surface at the base of a slide as a slope strata-concordant shear fracture, with localized stress concentrations occurring near the perimeter of the region undergoing sliding. The slide exerts significant in-plane stress concentrations and lateral compressional stress against flanking slope sediments. These stresses cause the development of contractional structures (e.g., thrusts) in the toe region, which nucleate on the evolving basal shear surface or zone, and that propagate upwards into overlying sediments. These discrete structures may be associated with related folds. The critical aspect of this model is that shearing, sliding, and basal shear surface or zone formation precedes significant deformation of the overlying sediment mass.

We argue this model can describe the styles and patterns of deformation observed here, given contractional strains (e.g., thrusts and folds) are present downslope of the present toe wall. We infer that the entire sediment mass between the slide toe wall, and the downdip limit of contractional strains beyond the toe wall, has undergone cryptic lateral translation. The relatively weakly deformed strata in this region (Fig. 10b, c) is essentially a giant megaclast. Only a few hundred metres (c. $100-200 \mathrm{~m}$ ) of lateral movement are required to account for the magnitude of contractional strains (e.g., thrust-related stratigraphic overlap or heave) observed downdip. Such a modest amount is consistent with the lack of erosional features (e.g., grooves) along the slide base (Fig. 5b). We propose a model by which the basal shear surface or zone incrementally propagates 
downdip ahead of the developing slide mass, with material above this level translating and possibly shortened before being incorporated into the main body of the evolving slide (Figs. 10 and 11). A similar mechanism, which involves the plucking of megaclasts from a dynamically deepening basal shear surface, is proposed by Ortiz-Karpf et al. (2017), based on their analysis of 3D seismic reflection data from offshore Colombia.

The basal shear surface varies along strike and the development of ramp and flat geometries on the basal shear surface of slides has been linked to variations in the geotechnical properties of the failing stratigraphy (e.g. Frey-Martinez et al. 2005; Solheim et al. 2005; Bull et al. 2009). Basal shear surfaces typically develop between sedimentary sequences with different shear strength and pore pressure regimes (e.g. Leynaud et al. 2007; Strasser et al. 2007). For example, sequences with higher shear strength (resulting from lower pore pressures) enable the basal shear surface to step up to shallower stratigraphic levels. Along strike variations in lithology and pore pressure could, therefore, lead to along-strike changes in basal shear surface and toewall geometry. For example, the stair-case like geometry observed in the NE of the studied slide may indicate that a more complex stratigraphy initially characterized the region. For example, stronger intervals may have separated two or more prominent weak layers (i.e. the basal shear surface 'flats') characterized by high pore pressure.

Our model for the basal shear surface evolution may have implications for our understanding of hazards of slides. Seafloor mapping involving bathymetric and seismic data may give insights into configuration, spatial distribution, and volume of slides failure. Our model based on the plausibility of scenario 2 suggests that slides can grow dynamically. In addition, very high internal strains can occur in response to minimal horizontal translation.

\section{Lateral variability in frontal confinement in the toe region}

Contractional strains typically dominate the toe region of slides due to buttressing of the translating sediment mass against the frontal toe wall (Frey-Martinez et al. 2006, Bull et al. 2009; Posamentier and Martinsen 2011). In the example presented here, the formation of NE-SW striking thrusts and pop-ups records this strain, which constitutes the first deformation phase. Asymmetrical folds are more widely reported from previous studies of slides (e.g., Suppe and Medwedeff. 1990; FreyMartínez et al. 2006; Alsop et al. 2017) and suggest (simple shear-style) shearing of a previously formed fold. We observe a more symmetrical style of folding. This can be related to the fact that our slide has not translated as far as other slides. We also note marked lateral variability in the style of frontal confinement, passing from several stair-case like geometries of two or three frontal walls in the northeast to only one frontal ramp in the southeast of the toe region.

Previous studies demonstrate the drop height (driving force) and depth of the basal shear surface (resisting force) are key controls on the degree of confinement at the front of submarine slides. Frey Martinez et al. (2006) argue that the depth to the basal shear surface effectively determines the cross-sectional aspect ratio of the failed slide. Thereby thick landslides can act differently than relatively thinner landslides. As a landslide loses potential energy downslope, it must gain energy to overcome and escape from its frontal ramp. Frey-Martinez et al. (2006) conclude that thicker landslides need more energy to ramp out on the seabed, thus tend to remain locked in their frontal confinement. Moernaut and De Batist (2011) demonstrate that the drop height influences the 
gravitational potential energy and thus the likelihood a slide will be frontally emergent. The same authors argue that friction along the basal shear surface is the key parameter restricting slide translation, thus limiting the likelihood a slide will be frontally emergent. Hence the interaction between these two parameters determines if a landslide becomes emergent or remains confined. Moernaut and De Batist (2011) conclude that emergent landslides have gravitational potential energy sufficient to exceed the potential energy required to ramp out of their stratigraphic position. However, these studies did not consider the along-strike changes in the basal shear surface. In this study, the along-strike changes in the basal shear surface and thus toe wall geometry mean that the relationship between the resisting and driving forces may also have varied. Considering the potential controls on the dynamics of the slide studied here (e.g., slope angle, slide thickness, drop height), we note that the top of the slide varies from c. $1740 \mathrm{~m}$ in its up-dip region in the translation zone to c. $3280 \mathrm{~m}$ in the frontal margin, yielding a minimum drop height of $1540 \mathrm{~m}$. The depth of the basal shear surface and the slide thickness vary laterally, i.e., the basal shear surface varies from c. $1840 \mathrm{~m}$ in the updip region to c. $3480 \mathrm{~m}$ in the frontal margin. Basal shear surface depths varies laterally in the frontal margin from c. $3480 \mathrm{~m}$ in the SE to c. $3190 \mathrm{~m}$ in the NE. Given that the driving forces are higher, accompanied by a thinner deposit, we observe more frontal emergence to the NE; conversely, where the slope is gentler and the slide more confined, the slide is thicker and the drop height smaller. Effectively, in the SE the run-out was shorter, and the resulting stresses resulted in slightly increased horizontal shortening, associated with the formation of thrust bound pop-up blocks.

\section{Lateral variability of intra-slide strain}

This study demonstrates that the translating slide mass underwent strike-slip shearing, resulting in the formation of sinistral shear zones (Figs. 9 and 10c). Similar structures are documented by Nugraha et al. (2019) and Steventon et al. (2019), who report shear zones and strike-slip deformation between flow cells. However, it is notable in this study that this style of deformation occurred after bulk shortening of the slide mass against the toe wall, after the formation of the thrust-bound pop-ups. The origin of this two-phase, non-coaxial deformation style is not clear. Early shortening in the toe region was likely associated with the expulsion of pore waters, and the compaction and embrittlement of the evolving rock mass, ultimately, leading to seismic-scale contraction structures. This process was spatially variable, possibly due to lateral changes in sediment porosity, pressure build-up, and the evolving rock strength, leading to the development of intra-slide flow cells and bounding shear zones, the former travelling downflow at different speeds and/or recording different total strains.

Slope-parallel shears are linked to lateral differences in the speed of slide transport and/or total strain (i.e., the total downslope movement of different parts of the slide; i.e., Masson et al. 1993; Gee et al. 2005; Bull et al. 2009; Omeru and Cartwright, 2019), with these differences potentially controlling the development of shear zone in our study. Unlike a single-celled model for slide development (e.g. Farrell 1984), our study, and those of other studies cited earlier, suggest several cells can be active during the formation of the slide. In addition to this, several sub-orthogonal sets or slope-oblique structures record internal shearing as downslope transport speeds and/or total strain varied during slide emplacement. The sub-orthogonal shears may also record a degree of 
transpression, providing evidence for a component of strike- and/or oblique-slip deformation

498 within the contractional domain.

499 In the cases cited above, the shear zones occurred during downslope formation of the slide, whereas we suggest the shear zones in the studied slide formed after shortening. There appears to be a spatial relationship between the two main NW-trending longitudinal shears bounding areas $\mathrm{A}$ and B, and areas B and C, and two major along-strike bends (from NE- to SE-trending) in the planview trace of the slide toe wall (e.g., Figs 8 and 9). However, it is clear there are numerous similar bends that are not associated with longitudinal shears, i.e., there are many more bends than there are shears, suggesting shear zone development is not genetically linked to along-strike/across-flow changes in slide toe wall geometry and degree of confinement.

\section{Conclusions}

We use a high-resolution 3D seismic reflection database to determine the kinematics of submarine slide emplacement, focusing on a seismically well-imaged Neogene slide in the Angoche Basin, offshore Mozambique. We show the toe region underwent two distinct phases of deformation: (i) bulk shortening, parallel to the overall SE-directed emplacement direction, accommodated by forming NE-trending, symmetrical, thrust-bound pop-up blocks; and (ii) the development of NWtrending sinistral shear zones that offset the earlier formed shortening structures and that separate flow cells reflecting along-strike variations in the rate and magnitude of downslope translation. A zone of somewhat subtle contractional deformation is also observed some distance beyond the toewall, in otherwise undeformed slope sediments. The slide exhibits varying degrees of frontal emergence along strike, with a single frontal toe wall in the SE and a more complex, staircase-like geometry in the NE. This along-strike variability likely reflects related along-strike differences in the forces driving slide transport and the geotechnical properties of the slope sediments. We propose a model in which the basal shear surface or zone incrementally propagates downdip and precedes significant deformation of the overlying slide mass, with material above this level being translated and possibly shortened before being incorporated into the main body of the evolving slide. Our model has implications for our understanding of hazards of slides: (i) slides can grow dynamically; and (ii) complex strains can occur in response to minimal horizontal translation.

\section{Acknowledgements}

We thank Instituto Nacional de Petróleo Mozambique (INP) and WesternGeco for supplying the data used for this study. We thank the editor and reviewers for the time and effort dedicated to providing feedback on our manuscript and are grateful for the detailed comments and valuable improvements made to our paper.

\section{References}

Alsop, G.I. and Marco, S. 2014. Fold and fabric relationships in temporally and spatially evolving slump systems: a multi-cell flow model. Journal of Structural Geology, 63, 27-49, https://doi.org/10.1016/j.jsg.2014.02.007 

Deposits. Journal of structural geology, 94, p.98-115

Alves, T.M. 2015. Submarine slide blocks and associated soft-sediment deformation in deep-water basins: a review. Marine and Petroleum Geology, 67, 262-285, https://doi.org/10.1016/j.marpetgeo.2015.05.010

541

542

543

544

545

546

547

548

549

550

551

552

553

554

555

556

557

558

559

560

561

562

563

564

565

566

567

568

569

570

571

572

573

Alves, T.M. and Cartwright, J.A. 2009. Volume balance of a submarine landslide in the Espírito Santo Basin, offshore Brazil: quantifying seafloor erosion, sediment accumulation and depletion. Earth and Planetary Science Letters, 288, 572-580, https://doi.org/10.1016/j.eps1.2009.10.020

Alves, T.M., Kurtev, K., Moore, G.F. and Strasser, M. 2014. Assessing the internal character, reservoir potential, and seal competence of mass-transport deposits using seismic texture: a geophysical and petrophysical approach. AAPG Bulletin, 98, 793-824, https://doi.org/10.1306/09121313117

Bull, S. and Cartwright, J.A. 2019. Line length balancing to evaluate multi-phase submarine landslide development: an example from the Storegga Slide, Norway. Geological Society, London, Special Publications, 500, 531-549, https://doi.org/10.1144/SP500-2019-168

Bull, S., Cartwright, J. and Huuse, M. 2009. A review of kinematic indicators from mass-transport complexes using 3D seismic data. Marine and Petroleum Geology, 26, 1132-1151, https://doi.org/10.1016/j.marpetgeo.2008.09.011

Butler, R. and McCaffrey, W. 2010. Structural evolution and sediment entrainment in masstransport complexes: outcrop studies from Italy. Journal of the Geological Society, London, 167, 617-631, https://doi.org/ 10.1144/0016-76492009-041

Cardona, S., Wood, L.J., Day-Stirrat, R.J. and Moscardelli, L. 2016. Fabric development and porethroat reduction in a mass-transport deposit in the Jubilee Gas Field, Eastern Gulf of Mexico: consequences for the sealing capacity of MTDs. Advances in Natural and Technological Hazards Research, 41, 27-37, https://doi.org/10.1007/978-3-319-20979-1_3

Cardona, S., Wood, L.J., Dugan, B., Jobe, Z. and Strachan, L.J. 2020. Characterization of the Rapanui mass-transport deposit and the basal shear zone: Mount Messenger Formation, Taranaki Basin, New Zealand. Sedimentology, 67, 2111-2148, https://doi.org/10.1111/sed.12697

Clare, M., Chaytor, J., Dabson, O., Gamboa, D., Georgiopoulou, A., Eady, H., Hunt, J., Jackson, C., Katz, O., Krastel, S., León, R., Micallef, A., Moernaut, J., Moriconi, R., Moscardelli, L., Mueller, C., Normandeau, A., Patacci, M., Steventon, M., Urlaub, M., Völker, D., Wood, L. and Jobe, Z. 2019. A Consistent Global Approach for the Morphometric Characterization of Subaqueous Landslides. Geological Society special publication, Vol.477 (1), p.455-477

Couvin, B., Georgiopoulou, A., Mountjoy, J.J., Amy, L., Crutchley, G.J., Brunet, M., Cardona, S., Gross, F., Böttner, C., Krastel, S. and Pecher, I. 2020. A new depositional model for the Tuaheni Landslide Complex, Hikurangi Margin, New Zealand. Geological Society special publication, Vol.500 (1), p.551-566 
Dasgupta, P. 2008. Experimental decipherment of the soft sediment deformation observed in the upper part of the Talchir Formation (Lower Permian), Jharia Basin, India. Sedimentary Geology, 205, 100-110.

Dahlstrom, C. 1969. Balanced cross sections. Canadian Journal of Earth Sciences, 6, 743-757, https://doi.org/10.1139/e69-069

Dott, R. 1963. Dynamics of subaqueous gravity depositional processes. AAPG Bulletin, 47, 104128.

Dunlap, D.B.,Wood, L.J., Weisebberger, C. and Jabour, H. 2010. Seismic geomorphology of offshore Morocco's east margin, Safi Haute Mer area. American Association of Petroleum Geologists Bulletin, 94, 615-642, https://doi.org/10.1016/j.marpetgeo.2008.09.011

Farrell, S.G. 1984. A dislocation model applied to slump structures, Ainsa Basin, South Central Pyrenees. Journal of Structural Geology, 6, 727-736, https:// doi.org/10.1016/01918141(84)90012-9

Francis, M., Milne, G., Kornpihl, D.K., Tewari, S., Rathee, D., Barlass, D. and Broadbent, K. 2017. Petroleum systems of the deepwater Mozambique Basin. First Break, 35(6) https://doi.org/2083/10.3997/1365-2397.35.6.89456

Frey-Martinez, J., Cartwright, J. and Hall, B. 2005. 3D seismic interpretation of slump complexes: examples from the continental margin of Israel. Basin Research, 17, 83-108, https://doi.org/10.1111/j.1365-2117.2005.00255.x

Frey-Martínez, J., Cartwright, J. and James, D. 2006. Frontally confined versus frontally emergent submarine landslides: a 3D seismic characterization. Marine and Petroleum Geology, 23, 585604, https://doi.org/10.1016/j.marpetgeo.2006.04.002

Gee, M., Gawthorpe, R. and Friedmann, J. 2005. Giant striations at the base of a submarine landslide. Marine Geology, 214, 287-294, https://doi.org/10.1016/j.margeo.2004.09.003

Gee, M.J., Masson, D.G., Watts, A.B. and Mitchell, N.C. 2001. Passage of debris flows and turbidity currents through a topographic constriction: seafloor erosion and deflection of flow pathways. Sedimentology, 48, 1389-1409,https://doi.org/10.1046/j.1365-3091.2001.00427.x

Gee, M., Uy, H., Warren, J., Morley, C. and Lambiase, J. 2007. The Brunei slide: a giant submarine landslide on the North West Borneo margin revealed by 3D seismic data. Marine Geology, 246, 9-23, https://doi.org/10.1016/j.margeo.2007.07.009

Guntoro, A. 1999. The formation of the Makassar Strait and the separation between SE Kalimantan and SW Sulawesi. Journal of Asian Earth Sciences,17, 79-98, https://doi.org/10.1016/S07439547(98)00037-3

Hodgson,D., Brooks, H., Ortiz-Karpf, A., Spychala, Y., Lee, D. and Jackson, C.A-L.2018. Entrainment and abrasion of megaclasts during submarine landsliding and their impact on flow behaviour. Geological Society, London, Special Publications, 477, 223-240, https://doi.org/10.1144/SP477.26 
Huvenne, V.A.I., Croker-Peter, F. and Henriet, J.P. 2002. A refreshing 3D view of an ancient sediment collapse and slope failure. Terra Nova, 14, 33-40, https://doi.org/10.1046/j.1365$\underline{3121.2002 .00386 . \mathrm{x}}$

Jacques, J.M., Wilson, K.L., Markwick, P.L. and Wright, D.G. 2006. The importance of the Davie transcurrent deformation zone on hydrocarbon prospectivity of the offshore blocks of the Rovuma and Tanzanian coastal basins. East Africa, AAPG International Conference and Exhibition, Extended Abstracts.

Jackson, C.A. 2011. Three-dimensional seismic analysis of megaclast deformation within a mass transport deposit; implications for debris flow kinematics. Geology, 39, 203-206, https://doi.org/10.1130/G31767.1

Joanne, C., Lamarche, G. and Collot, J.Y. 2013. Dynamics of giant mass transport in deep submarine environments: The Matakaoa Debris Flow, New Zealand. Basin Research 25, 471-488, doi: 10.1111/bre.12006.

Laake, A. 2015. Structural interpretation in color - A new RGB processing application for seismic data. Interpretation 3(1), pp. SC1-SC8.

Leynaud, D., Sultan, N., Mienert, J., 2007. The role of sedimentation rate and permeability in the slope stability of the formerly glaciated Norwegian continental margin: the Storegga Slide model. Landslides 4 (4), 297-309.

Mahanjane, E.S. 2014. The Davie Fracture Zone and adjacent basins in the offshore Mozambique Margin: A new insight for the hydrocarbon potential Marine and Petroleum Geology, 57, 561-571. https://doi.org/10.1016/j.marpetgeo.2014.06.015

Mahanjane, E.S., and Franke, D., 2014. The Rovuma Delta deep-water fold-and-thrust belt, offshore Mozambique. Tectonophysics 614, 91-99. http://dx.doi.org/10.1016/j.tecto.2013.12.017.

Martel, S.J., 2004. Mechanics of landslide initiation as a shear fracture phenomenon. Marine Geology 203, 319-339.

Martinsen, O.J., 1989. Styles of soft-sediment deformation on a Namurian (Carboniferous) delta slope, western Irish Namurian Basin, Ireland. In: Whateley, M.K.G., Pickering, K.T. (Eds.), Deltas: Sites and Traps for Fossil Fuels. Geological Society of London Special Publication, vol. 210. pp. 167-177.

Martinsen, O. and Bakken, B. 1990. Extensional and compressional zones in slumps and slides in the Namurian of County Clare, Ireland. Journal of the Geological Society, London, 147, 153-164, https://doi.org/10.1144/gsjgs.147. 1.0153

Masson, D., Huggett, Q. and Brunsden, D. 1993. The surface texture of the Saharan debris flow deposit and some speculations on submarine debris flow processes. Sedimentology, 40, 583-598, https://doi.org/10.1111/j.1365-3091. 1993.tb01351.x 
Masson, D.G., Harbitz, C.B., Wynn, R.B., Pedersen, G and Løvholt, F. 2006. Submarine landslides: processes, triggers and hazard prediction. Phil. Trans. R. Soc. A.3642009-2039. http://doi.org/10.1098/rsta.2006.1810

McGilvery, T.A., Haddad, G. and Cook, D.L. 2004. Seafloor and shallow subsurface examples of mass transport complexes, Offshore Brunei. Onshore Technology Conference, Houston, TX.

Minisini, D., Trincardi, F., Asioli, A., Canu, M. and Foglini, F. 2007. Morphologic variability of exposed mass transport deposits on the eastern slope of Gela Basin (Sicily channel). Basin Research, 19, 217-240.

Moore, G.F., Saffer, D., Studer, M. and Pisani, P.C. 2011. Structural restoration of thrusts at the toe of the Nankai Trough accretionary prism off Shikoku Island, Japan: implications for dewatering processes.

Moernaut, J. and De Batist, M. 2011. Frontal emplacement and mobility of sub lacustrine landslides: Results from morphometric and seismostratigraphic analysis. Marine Geology 285, 2945 .

Moscardelli, L.,Wood, L. and Mann, P. 2006. Mass-transport complexes and associated processes in the Offshore Area of Trinidad and Venezuela. AAPG Bull., 90, 1059-1088.

Moscardelli, L. and Wood, L. 2008. New classification system for mass transport complexes in offshore Trinidad. Basin Research, 20, 73-98, https://doi.org/10.1111/j.1365-2117.2007.00340.x

Nardin, T.R., Hein, F., Gorsline, D.S. and Edwards, B. 1979. A review of mass movement processes sediment and acoustic characteristics, and contrasts in slope and base-of-slope systems versus canyon-fan-basin floor systems. SEPM Special Publications, 27, 61-74.

Nemec, W. 1991. Aspects of sediment movement on steep delta slopes. International Association of Sedimentologists, Special Publications, 10, 29-73.

Nugraha, H.D., Jackson, C.A.L., Johnson, H.D. and Hodgson, D.M. 2020. Lateral variability in strain along the toewall of a mass transport deposit; a case study from the Makassar Strait, offshore Indonesia. Geological Society of London, 177, 1261-1279. https://doi.org/10.1144/jgs2020-071

Ogata, K., Mutti, E., Pini, G.A. and Tinterri, R. 2012. Mass transport-related stratal disruption within sedimentary mélanges: examples from the northern Apennines (Italy) and south-central Pyrenees (Spain). Tectonophysics, 568, 185-199, https://doi.org/10.1016/j.tecto.2011.08.021

Ogata, K., Mountjoy, J., Pini, G.A., Festa, A. and Tinterri, R. 2014a. Shear zone liquefaction in mass transport deposit emplacement: a multi-scale integration of seismic reflection and outcrop data. Marine Geology, 356, 50-64, https://doi.org/10.1016/j.margeo.2014.05.001

Ogata, K., Pogacnik, Z, Pini, G.A., Tunis, G., Festa, A., Camerlenghi, A. and Rebesco, M. 2014 b. The carbonate mass transport deposits of the Paleogene Friuli Basin (Italy/Slovenia): internal anatomy and inferred genetic processes. Marine Geology, 356, 88-110, https://doi.org/10.1016/j.margeo.2014.06.014 
Ogata, K., Festa, A., Pini, G., Pogacnik, Z and Lucente, C. 2019. Substrate deformation and incorporation in sedimentary mélanges (olistostromes): examples from the northern Apennines (Italy) and northwestern Dinarides (Slovenia). Gondwana Research, 74, 101-125, https://doi.org/10.1016/j.gr.2019.03.001.

Olafiranye, K., Jackson, C.A.-L. and Hodgson, D.M. 2013. The role of tectonics and masstransport complex emplacement on upper slope stratigraphic evolution: a 3D seismic case study from offshore Angola. Mar. Pet. Geol., 44, 196-216.

Omeru, T. and Cartwright, J.A. 2019. The efficacy of kinematic indicators in a complexly deformed mass transport deposit: insights from the deepwater Taranaki Basin, New Zealand. Marine and Petroleum Geology, 106, 74-87,https://doi.org/10.1016/j.marpetgeo.2019.04.037

Ortiz-Karpf, A., Hodgson, D.M. \& Mccaffrey, W.D. 2015. The role of mass-transport complexes in controlling channel avulsion and the subsequent sediment dispersal patterns on an active margin: the Magdalena Fan, offshore Colombia. Marine and Petroleum Geology, 64, 58-75, https://doi.org/10.1016/j.marpetgeo. 2015.01.005

Ortiz-Karpf, A., Hodgson, D.M., Jackson, C.A.-L. and Mccaffrey, W.D. 2017. Influence of seabed morphology and substrate composition on mass-transport flow processes and pathways: insights from the Magdalena Fan, offshore Colombia. Journal of Sedimentary Research, 87, 189-209, https://doi.org/10.2110/jsr.2017.10

Ortiz-Karpf, A., Hodgson, D.M., Jackson, C.A.-L. and Mccaffrey, W.D. 2018. Mass-transport complexes as markers of deep-water fold-and-thrust belt evolution: insights from the southern Magdalena Fan, offshore Colombia. Basin Research, 30, 65-88, https://doi. org/10.1111/bre.12208

Pedersen, S.I., Randen, T., Sønneland, L. and Steen, Ø. 2002. Automatic fault extraction using artificial ants. SEG Annual Meeting. (Conference Paper)

Posamentier, H.W. and Kolla, V. 2003. Seismic geomorphology and stratigraphy of depositional elements in deep-water settings. Journal of Sedimentary Research, 73, 367-388, https://doi.org/10.1306/111302730367

Posamentier, H.W. and Martinsen, O.J. 2011. The character and genesis of submarine masstransport deposits: insights from outcrop and 3D seismic data. SEPM, Special Publications, 96, 738, https://doi.org/10.2110/sepmsp.096.007.

Prior, D.B., Bornhold, B.D. and Johns, M.W. 1984. Depositional characteristics of a submarine debris flow. Journal of Geology, 92, 707-727, https://doi.org/10.1086/ 628907

Ramsey, J.C. and Lisle, R.J. 2000. The Techniques of Modern Structural Geology. Academic Press, London.

Reeves, C. and Mahanjane, E.S., 2013. Mozambique and its role in the downfall of Gondwana. Geological Society of Houston/Petroleum Exploration Society of Great Britain, London, 2013 September 11-12. http://pesgb.org.uk/events/event-165/. 
Reis, A.T., Araújob, E. 2016. Effects of a regional décollement level for gravity tectonics on late Neogene to recent large-scale slope instabilities in the Foz do Amazonas Basin, Brazil. Marine and Petroleum Geology, 75, 29-52, https://doi.org/10.1016/j.marpetgeo. 2016.04.011

Salman, G. and Abdula, I., 1995. Development of the Mozambique and Ruvuma sedimentary basins, offshore Mozambique. Sedimentary Geology 96, 7-41. Elsevier Science B.V. SSDI 00370738(94)00125-1.

Sammartini, M., Moernaut, J., Kopf, et al., Propagation of frontally confined subaqueous landslides: Insights from combining geophysical, sedimentological, and geotechnical analysis, Sedimentary Geology (2021), https://doi.org/10.1016/j.sedgeo.2021.105877

Sapri, D.H., Mahmud, O.T. and Wong Wi Chenm, H. 2013. Sequence Stratigraphic Study of Areas 3 \& 6, Rovuma Basin Mozambique. International Petroleum Technology Conference IPTC, Extended Abstracts.

Scarselli, N., Mcclay, K. \& Elders, C. 2013. Submarine Slide and Slump Complexes, Exmouth Plateau, NW Shelf of Australia. In: Western Australian Basins Symposium 2013, Aug 18-21 2013 Perth (Ed. by M. Keep \& S.J. Moss). Petroleum Exploration Society of Australia.

Schnellmann, M., Anselmetti, F.S., Giardini, D. and McKenzie, J.A. 2005. Mass movementinduced fold-and-thrust belt structures in unconsolidated sediments in Lake Lucerne (Switzerland). Sedimentology, 52, 271-289, https://doi.org/10.1111/j.1365-3091.2004.00694.X

Smith, W. H. F., and Sandwell, D.T. 1997. Global seafloor topography from satellite altimetry and ship depth soundings, Science, v. 277, 1957-1962.

Sobiesiak, M.S., Kneller, B., Alsop, G.I. and Milana, J.P. 2018. Styles of basal interaction beneath mass transport deposits. Marine and Petroleum Geology, 98, 629-639, https://doi.org/10.1016/j.marpetgeo.2018.08.028

Sobiesiak, M.S., Buso, V.V., Kneller, B., Alsop, G.I. and Milana, J.P. 2019. Block generation, deformation, and interaction of mass-transport deposits with the seafloor: an outcrop-based study of the Carboniferous Paganzo Basin (Cerro Bola, NW Argentina). American Geophysical Union, Geophysical Monograph Series, 246, 91-104, https://doi.org/10.1002/9781119500513.ch6

Solheim, A., Berg, K., Forsberg, C.F., Bryn, P., 2005. The Storegga Slide: repetitive large scale sliding with similar cause and development. Marine and Petroleum Geology 22, 97-107.

Steventon, M.J., Jackson, C.A., Hodgson, D.M. and Johnson, H.D. 2019. Strain analysis of a seismically imaged mass-transport complex, offshore Uruguay. Basin Research, 31, 600-620, https://doi.org/10.1111/bre.12337

Strasser, M., Anselmetti, F.S., Fah, D., Giardini, D., Schnellmann, M., 2006. Magnitudes and source areas of large prehistoric northern Alpine earthquakes revealed by slope failures in lakes. Geology 34 (12), 1005-1008. 
Strasser, M., Stegmann, S., Bussmann, F., Anselmetti, F.S., Rick, B., Kopf, A., 2007. Quantifying subaqueous slope stability during seismic shaking: Lake Lucerne as model for ocean margins. Marine Geology 240 (1-4), 77-97.

Suppe, J. and Medwedeff, D.A. 1990. Geometry and Kinematics of Fault Propagation Folding. Eclogae Geologicae Helvetiae, 83, 409-454.

Totake, Y., Butler, R.W., Bond, C.E. and Aziz, A. 2018. Analyzing structural variations along strike in a deep-water thrust belt. Journal of Structural Geology, 108, 213-229, https://doi.org/10.1016/j.jsg.2017.06.007

Trincardi, F. and Argnani, A. 1990. Gela submarine slide: a major basin-wide event in the PlioQuaternary foredeep of Sicily. Geo-Mar. Lett., 10, 13-21.

Van der Merwe, W., Hodgson, D., \& Flint, S. 2009. Widespread syn-sedimentary deformation on a muddy deep-water basin-floor: The Vischkuil Formation (Permian), Karoo Basin, South Africa. Basin Research , 21 , 389 - 406 . https://doi.org/10.1111/j.1365-2117. 2009.00396.x

Van Der Merwe, W.C., Hodgson, D.M. and Flint, S.S. 2011. Origin and terminal architecture of a submarine slide: a case study from the Permian Vischkuil Formation, Karoo Basin, South Africa. Sedimentology, 58, 2012-2038, https://doi.org/10.1111/j.1365-3091.2011.01249.x

Van Bemmel , P. P. , \& Pepper, R. E. 2000. Seismic signal processing method and apparatus for generating a cube of variance values. Google Patents.

Watt, S., Talling, P., et al. 2012. Widespread and progressive seafloor-sediment failure following volcanic debris avalanche emplacement: landslide dynamics and timing offshore Montserrat, Lesser Antilles. Marine Geology, 323, 69-94, https://doi.org/10.1016/j.margeo.2012.08.002

Weimer, P. 1990. Sequence stratigraphy, facies geometries, and depositional history of the Mississippi Fan, Gulf of Mexico (1) . AAPG Bulletin , 74 , 425 - 453.

Weimer, P. and Shipp, C. 2004. Mass transport complexes: musing on past uses and suggestions for future directions. Offshore Technology Conference, 3-6 May 2004, Houston, TX, USA, https://doi.org/10.4043/16752-MS

Wu, N., Jackson, CA., Johnson, H.D., Hodgson, D.M. and Nugraha, H.D. 2020. Mass-transport complexes (MTCs) document subsidence patterns in a northern Gulf of Mexico salt minibasin. Basin Research, 32, 1300-1327, https://doi.org/10.1111/bre.12429

Wu, N., Jackson, CA-L., Johnson, H.D., Hodgson, D.M., Clare, M.A., and Nugraha, H.D. 2020. The formation and implications of giant blocks and fluid escape structures in submarine lateral spreads. Basin Research. ISSN 0950-091X (In Press)

Zeng, H., Henry, S.C. and Riola, J.P. 1998. Stratal slicing, Part II: real 3-D seismic data. Geophysics, 63, 514-522, https://doi.org/10.1190/1.1444352

\section{Figure captions}


Figure 1. The location of the study area and bathymetric map of the Angoche Basin, offshore Mozambique (Sandwell and Smith 1997). The Angoche basin is located between the Rovuma basin to the north and the Zambezi basin to the south. An outline of the 3D time seismic surveys is represented by the green and blue lines that cover areas of c. $15,041 \mathrm{~km} 2$ and c. $4765 \mathrm{~km} 2$. The black line represents a depth-migrated volume that covers $2545 \mathrm{~km} 2$. Drilled wells are represented by black filled circles and field outlines are colored red in the inset map. There are no wells drilled in the Angoche basin. The blue lines represents key river systems and lakes. Bathymetric contours are shown by the black lines in $500 \mathrm{~m}$ increments.

Figure 2. Stratigraphic chart of the Angoche basin modified from Mahanjane 2014. The stratigraphic chart illustrates narrow elongate basins that hosts lacustrine and lagoonal sediments during the Middle Jurassic and potential source rocks. The Mozambique basin opens between Mozambique in the west and Antarctica in the east. The Davie Fracture Zone becomes active during the Middle Jurassic. Fault movement along the DFZ is dextral strike-slip. Strike-slip movement along the DFZ ceases during the Aptian and the basin gently fills with clastics. The Neogene records the influence of the East African Rift System and increased seismic episodes leading to the emplacement of thick extensive submarine landslides.

Figure 3. (A) Dip seismic section, (B) geoseismic section, through the central part of the 3D broadband time-migrated seismic reflection data that covers c. $15,041 \mathrm{~km}^{2}$. Chaotic packages, representing submarine landslides, are prominent throughout the Neogene interval. We focus on a well-imaged slide located $620 \mathrm{~ms}$ to $3637 \mathrm{~ms}$ (c. 599-3483 m) beneath the seabed. The slide has a maximum depositional length of c. $85 \mathrm{~km}$, an area of $3746 \mathrm{~km} 2$, a maximum thickness of c. 447 $\mathrm{ms}(380 \mathrm{~m})$, and a total volume of c. $530 \mathrm{~km} 3$. The slide's age is put in context of regional 2D interpretations that tie well information from the Rovuma basin to the north and some wells in the Zambezi Basin to the south.

Figure 4. (A) Dip seismic section illustrating structural geometries developed in the toe region. The slide is bound by a basal-shear surface (orange) at the base and a top surface (blue) at the top. The basal shear surface cuts up through stratigraphy to define the slides lateral margins. A steep frontal ramp (c. 210m.) defines the downdip limit of the toe region. (B-C) Strike seismic sections highlighting the geometry and scale of the slide lateral margins. The basal-shear surface shows discontinuities in the form of ramps that locally discordant to underlying stratigraphy.

Figure 5. (A) Thickness map of the slide between the basal-shear surface and the top surface illustrating significant thickening in the toe region. The slide has a maximum thickness of c. 447 $\mathrm{ms}(380 \mathrm{~m})$, and a total volume of c. $530 \mathrm{~km} 3$. It is c. $46 \mathrm{~km}$ wide in its central part and narrows downdip to c. $26 \mathrm{~km}$ in its toe region. (B) a map-view of the variance attribute extracted from the basal shear surface. Several kinematic indicators are observable, including the slide lateral margins. The slide terminates across-strike against a lateral margin that trends parallel to the gross SE-directed emplacement direction and its lateral margin is defined by a clear, linear, steep, continuous scarp that is up to $300 \mathrm{~ms}$ high and ultimately links to the frontal ramp in the toe region.

Figure 6. Seismic facies description used in this study. (A) RGB attribute extraction from an isoproportional slice (midway between the basal shear surface and the top surface). (B-D) Vertical 
sections showing seismic facies SF1 - SF3 within the slide. SF1 is characterised by very lowamplitude, chaotic reflections. SF2 typifies variable to high-amplitude, continuous reflections, which are folded and offset by thrusts. SF3 are high-amplitude isolated blocks inferred to be megaclasts encased within a debritic matrix.

Figure 7. Toe region of the slide. (A) Variance time slice within the internal body of the slide, uninterpreted. (B) The interpreted map highlights the lateral margins, well developed fold-andthrust structures and illustrates the internal interaction between slope-parallel shears 'longitudinal' and slope-oblique shears or sub-orthogonal in the toe region of the slide.

Figure 8. (A) Perspective 3D view of the subsurface elevation of the basal shear surface of the slide within the toe region of the slide highlighting the strike variability in the frontal ramp geometry. (B) Amplitude contrast extraction using a proportional slice between the basal shear surface and the top surface that illustrates key kinematic indicators including impressive thrust structures and pop-up blocks, uninterpreted. (C) Interpreted 3D view using a proportional slice between the basal shear surface and the top surface and approximates $90 \mathrm{~ms}$ above the basal shear surface. This figure illustrates key kinematic indicators, including thrust structures and pop-up blocks and shear zones within the toe region.

Figure 9. 3D distribution of key kinematic features and the relationships between intra-slide structures. The display highlights the entrainment of megaclasts within the internal body of the deposit and the relative positions of the shear zones that separate flow cells reflecting along-strike variations in the rate of downslope translation.

Figure 10. (A) Dip seismic sections illustrating contractional structures forming ahead of the flow and entrainment of large fragments from seabed as the debrite flowed. (B-C) Dip seismic sections highlights progressive imbrication downslope and the formation of regularly spaced pop-up blocks bounded by thrust planes. The basal shear surface or zone incrementally propagates downdip ahead of the developing slide mass (D) Vertical seismic section illustrates the material above the basal shear surface is fully incorporated into the main body of the slide.

Figure 11. (A-B) illustrates the distributed shear zone formed ahead of the slides frontal toe wall. Note location of this figure in relation to larger slide in Figure 10.

Figure 12. Quantitative analysis of shortening strains associated with a thrust-bound pop-up block in the submarine landslide toe region. (A) Depth-structure map of H1 and associated faults. (B) Antrack extraction showing the lateral extent of pop-up block 10. Two shear zones separate the flow cells that have varying amounts of strain. Sinistral offsets are evident across the shear zone in the SW; more subtle offsets are seen to the NE. (C) Inset map showing location of the pop-up block relative to the studied slide. (D)Throw v. distance $(T-x)$ plot of fore- and back-thrusts bounding pop-up block 10. (E-F) Seismic sections showing the along strike variability of the faults bounding pop-up block 10 .

Figure 13. (A-B) Emplacement model describing the slide and debrite as being genetically related, scenario 2. Slope failure occur due to pore pressure build-up along a discrete layer or closely 
875 spaced layers and reduced shear strength of interval. The slide ploughs and incorporates material 876 ahead of it, forming folds and thrusts. Note that the shear fracture deformation at depth precedes 877 large displacements in the slide mass. (C) Impressive contractional structures formed in the region. 878 (D-F)Vertical seismic sections showing relationship between overlying debrite and thrust bound 879 pop-up blocks in the toe region. 


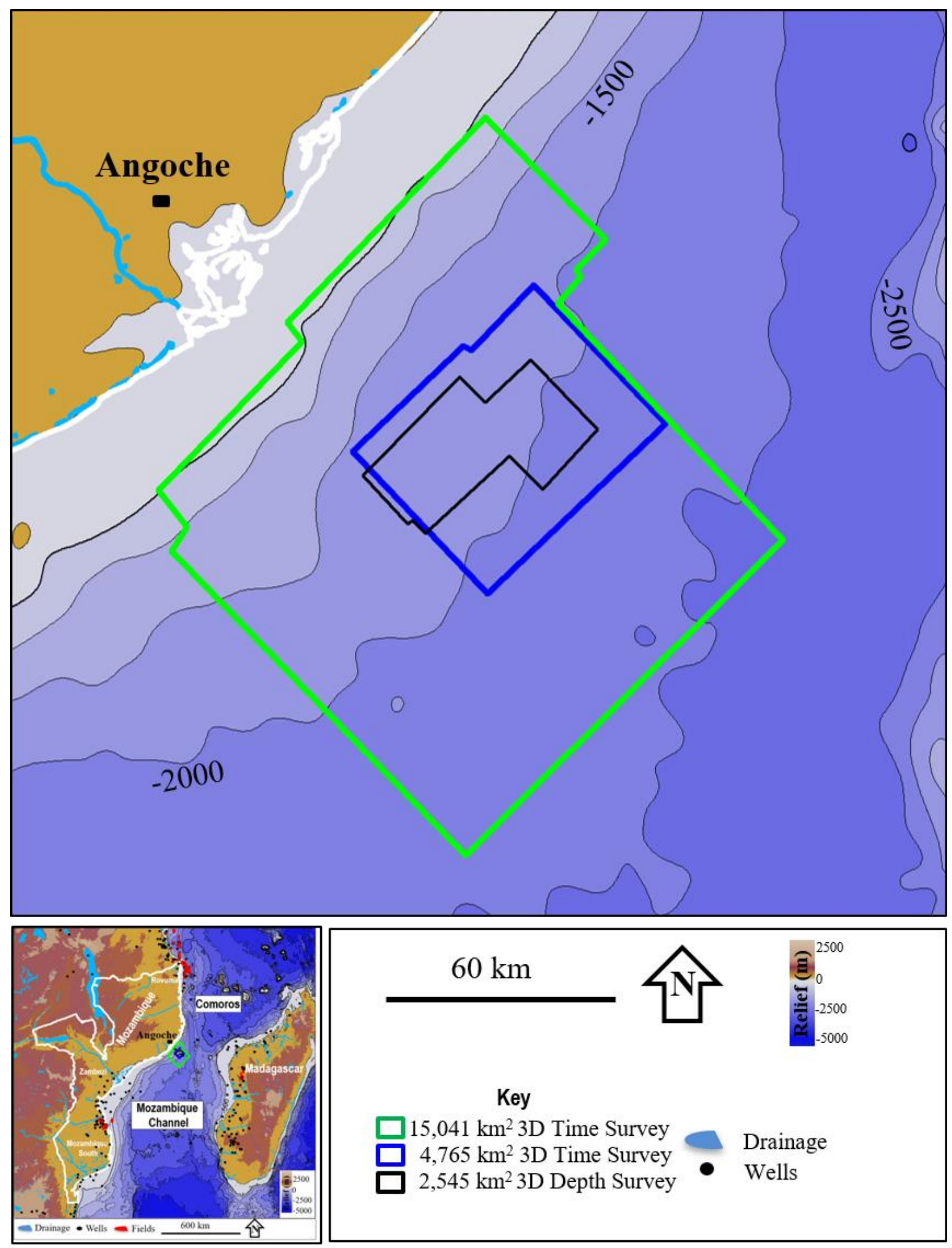

Figure 1 


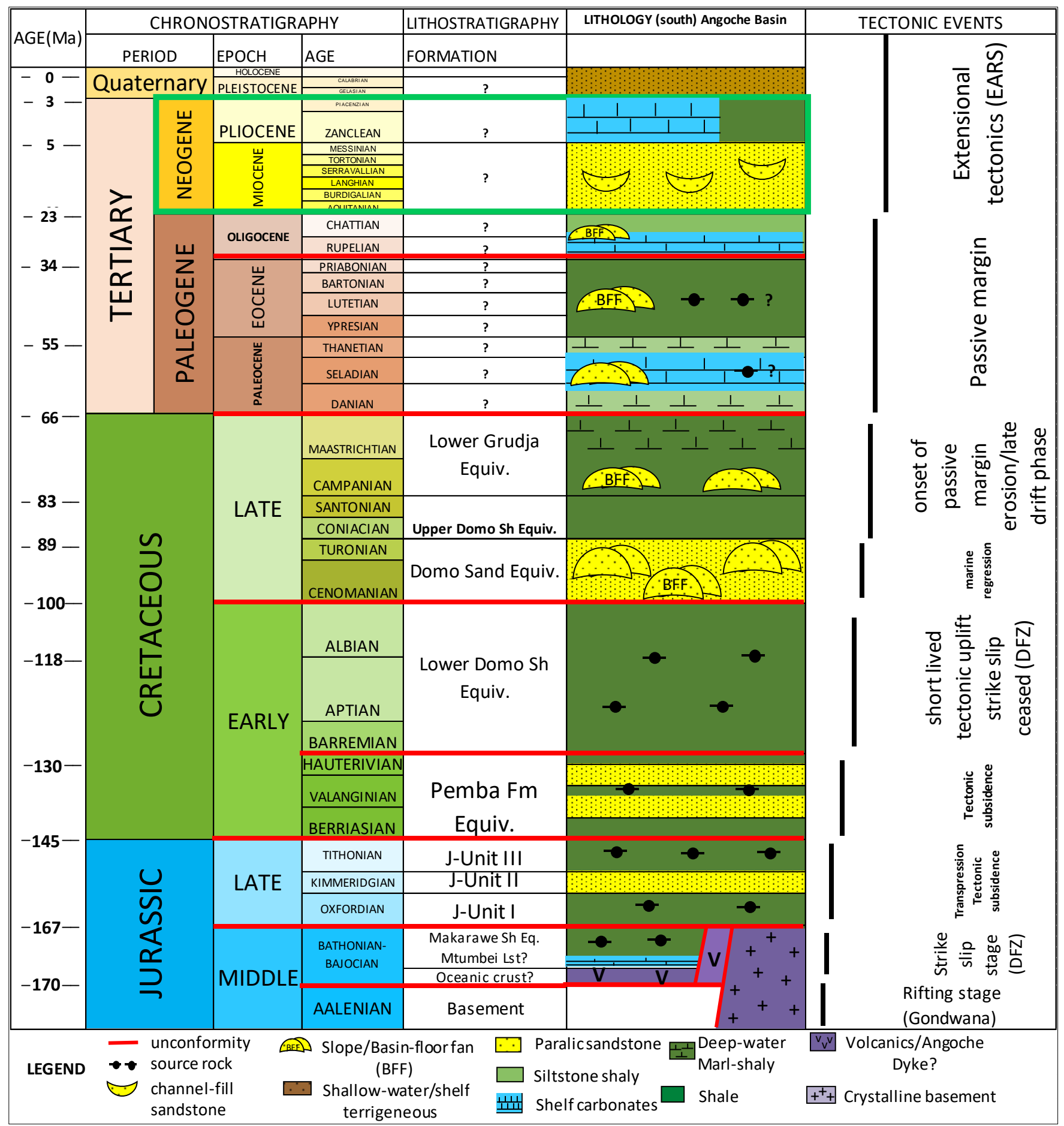

Figure 2 


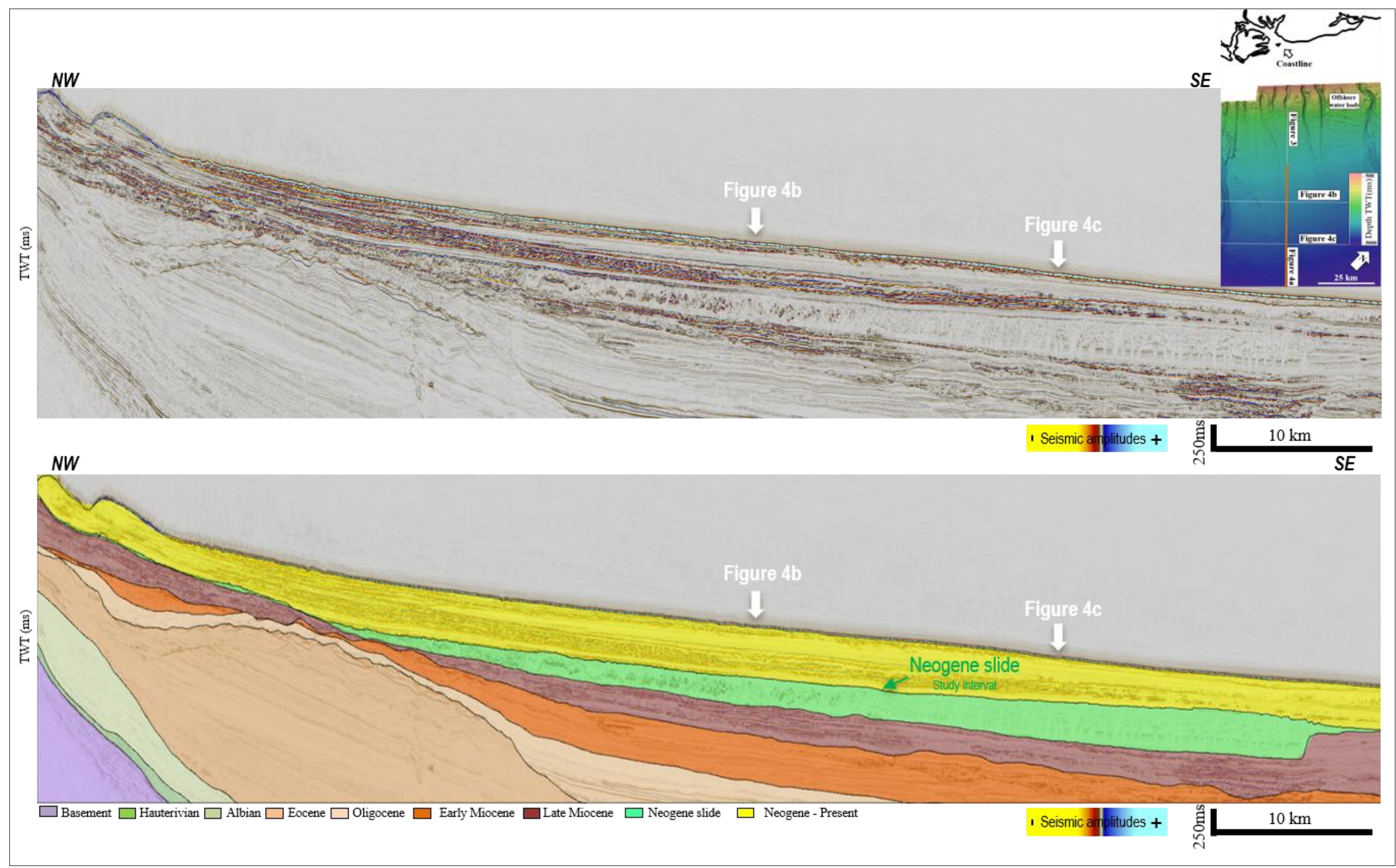

Figure 3 


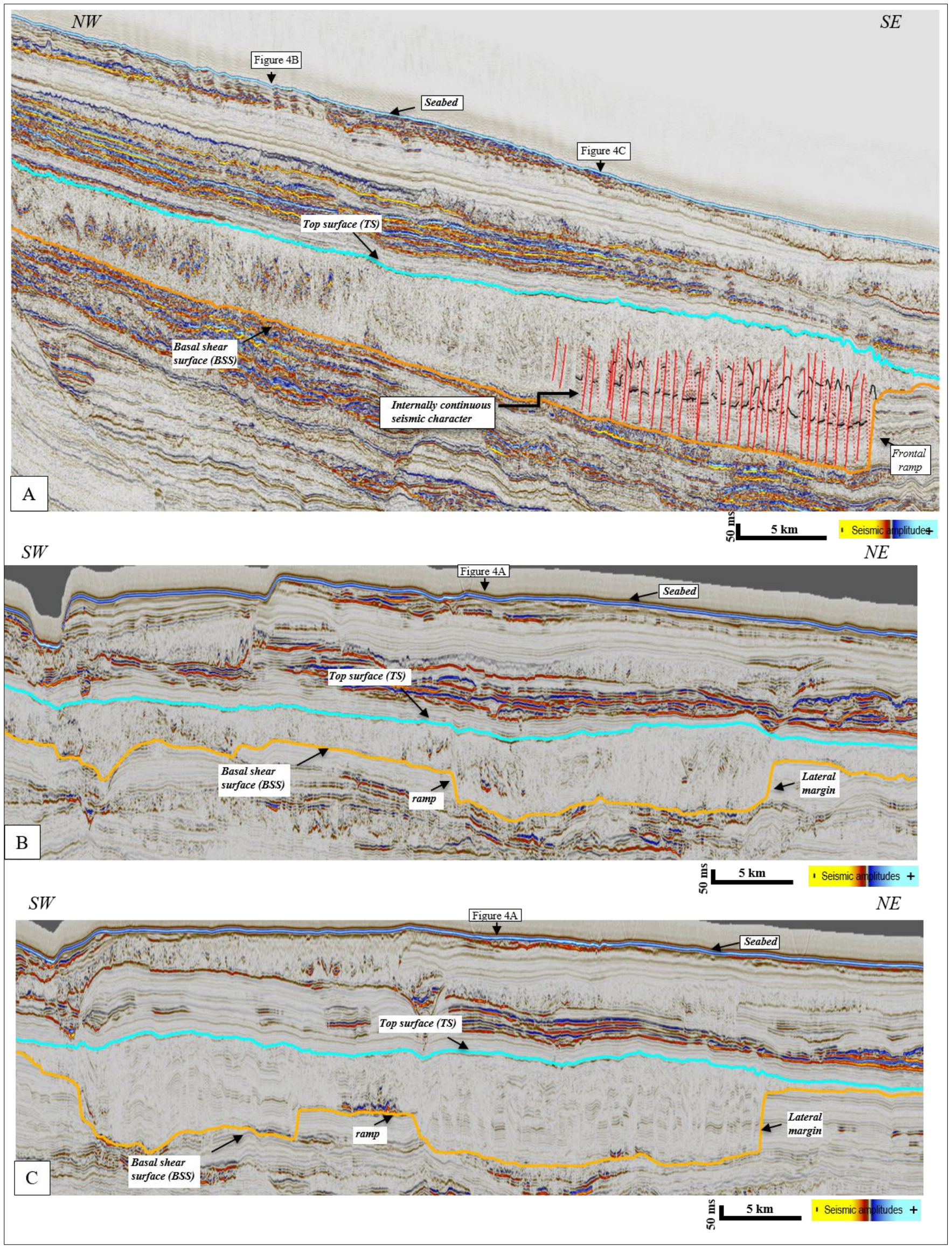

Figure 4 


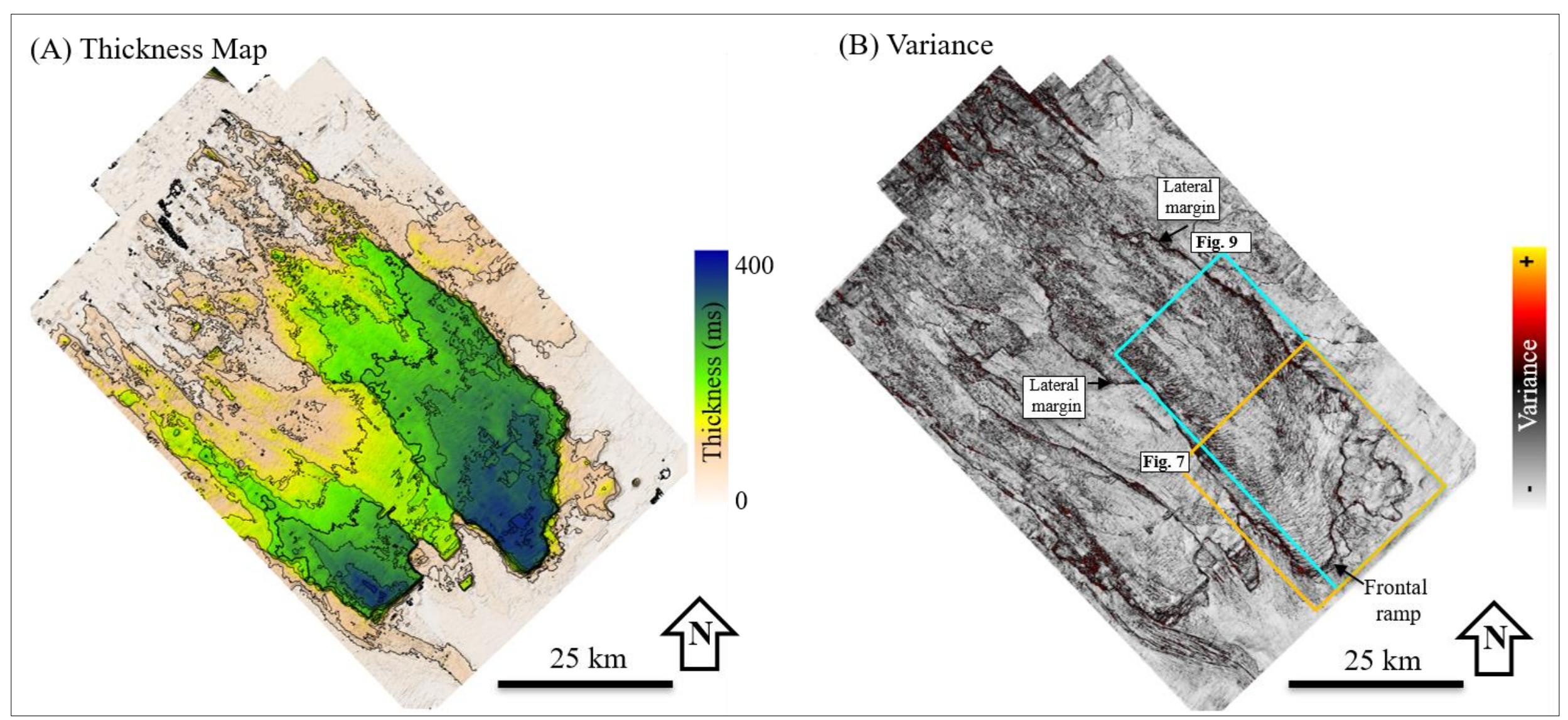

Figure 5 


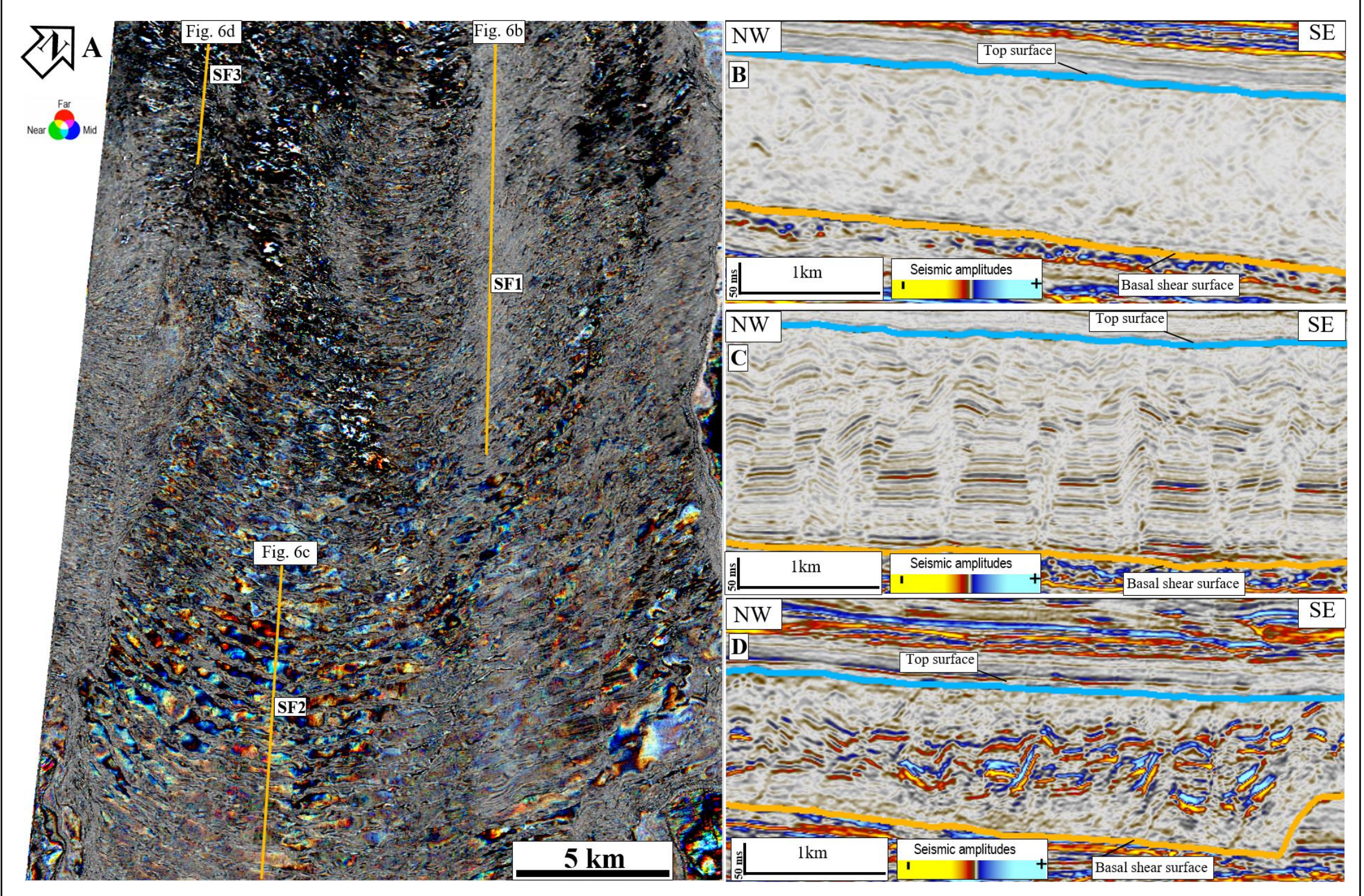

Figure 6 


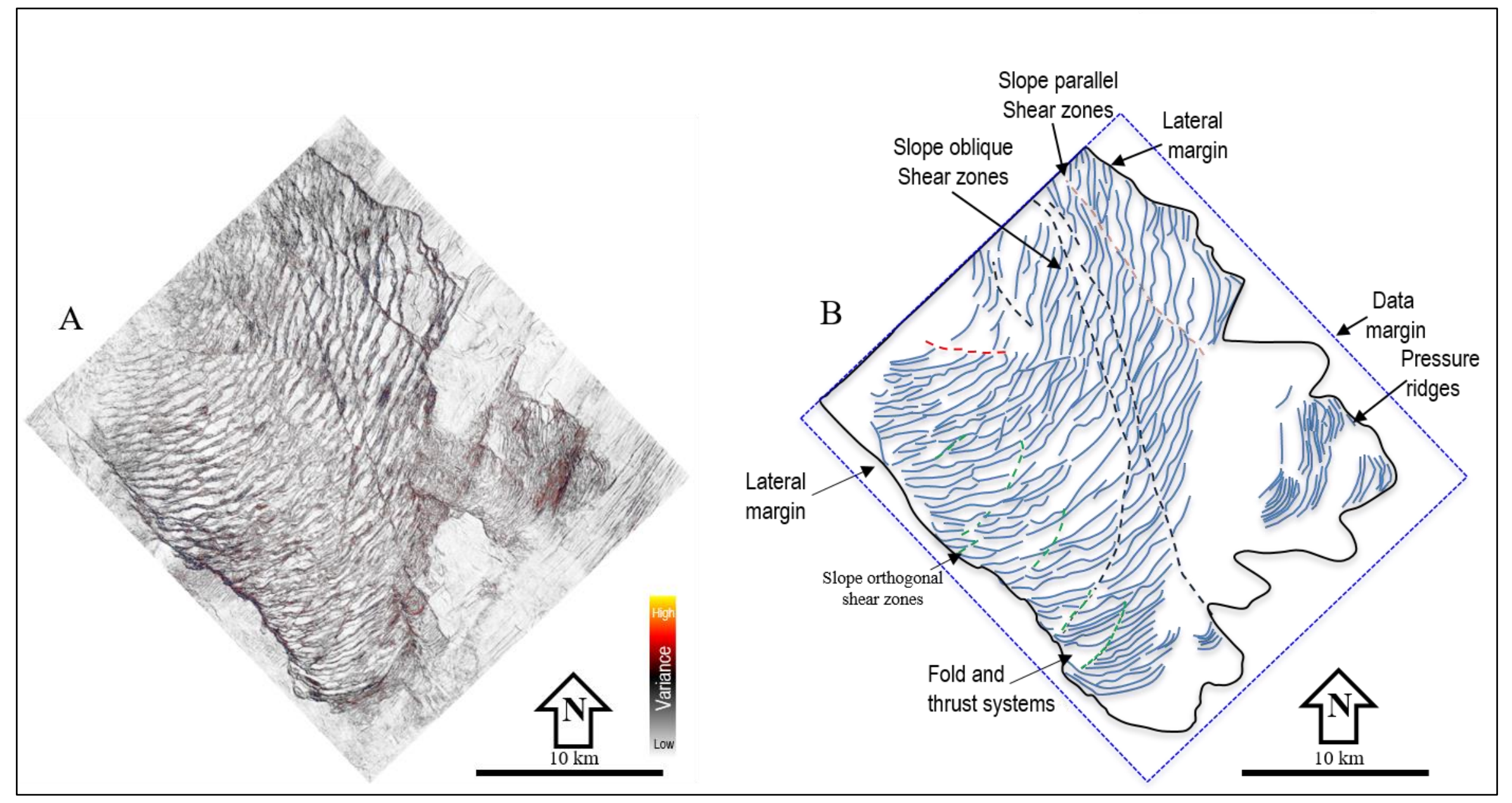

Figure 7 


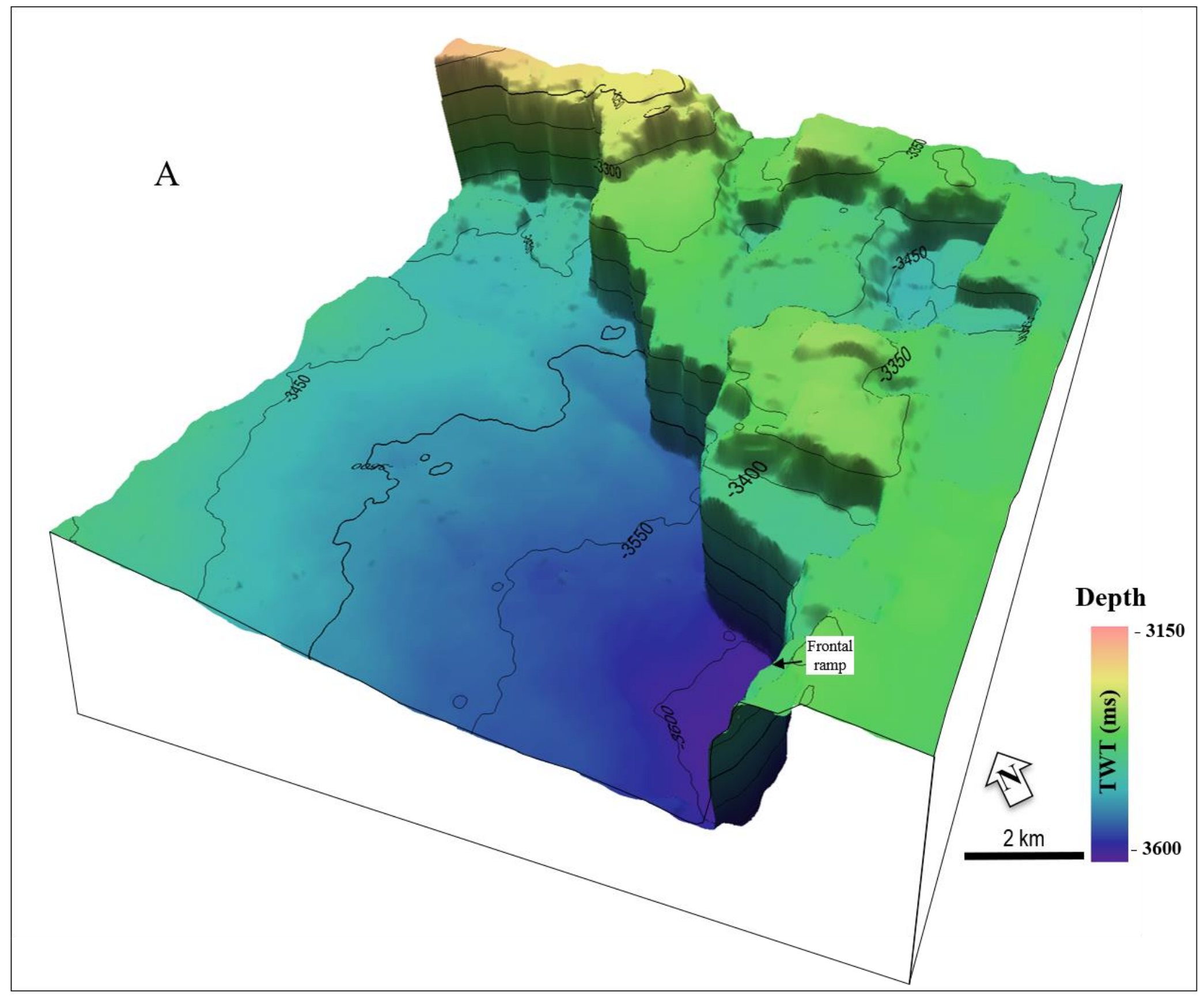




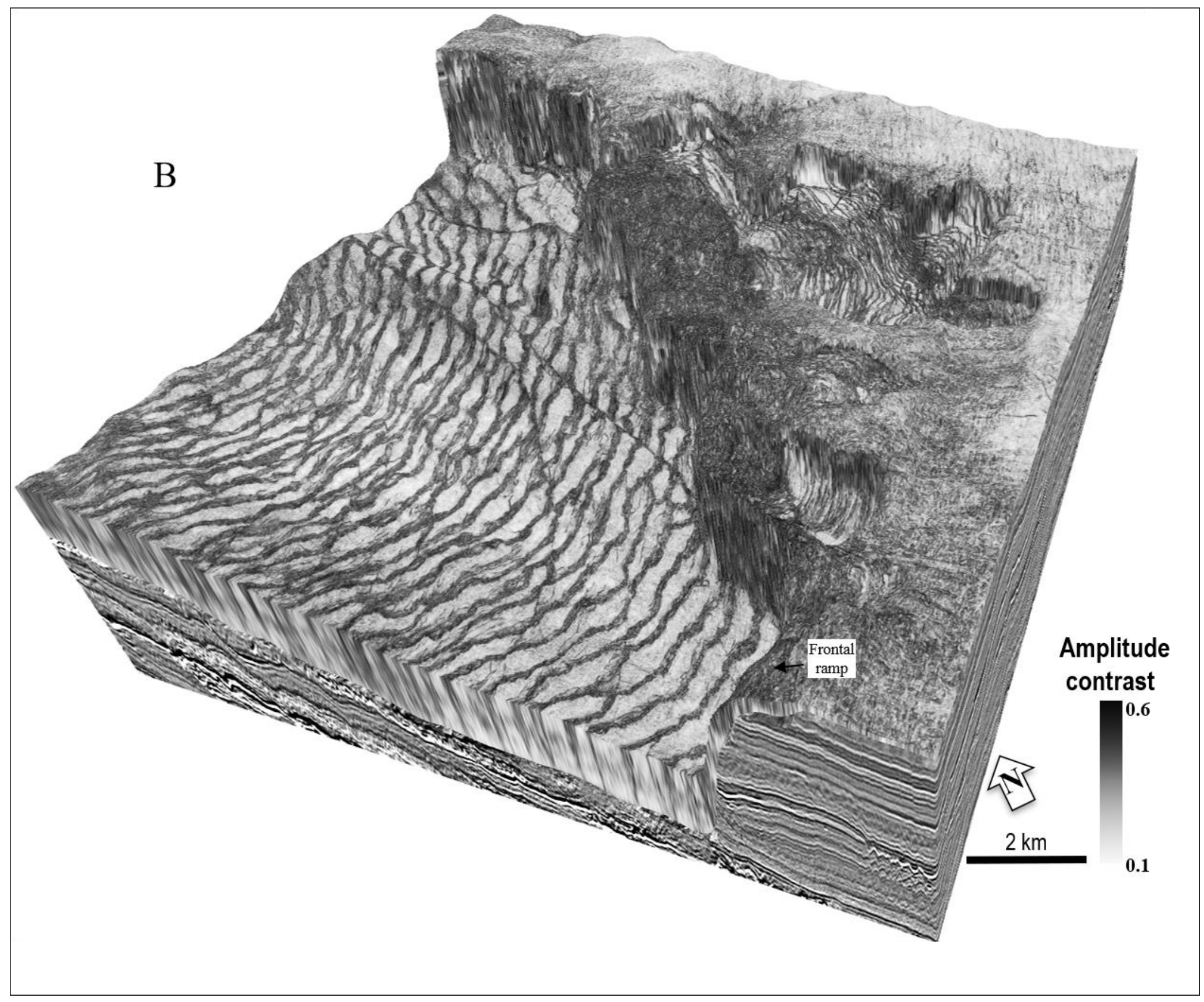




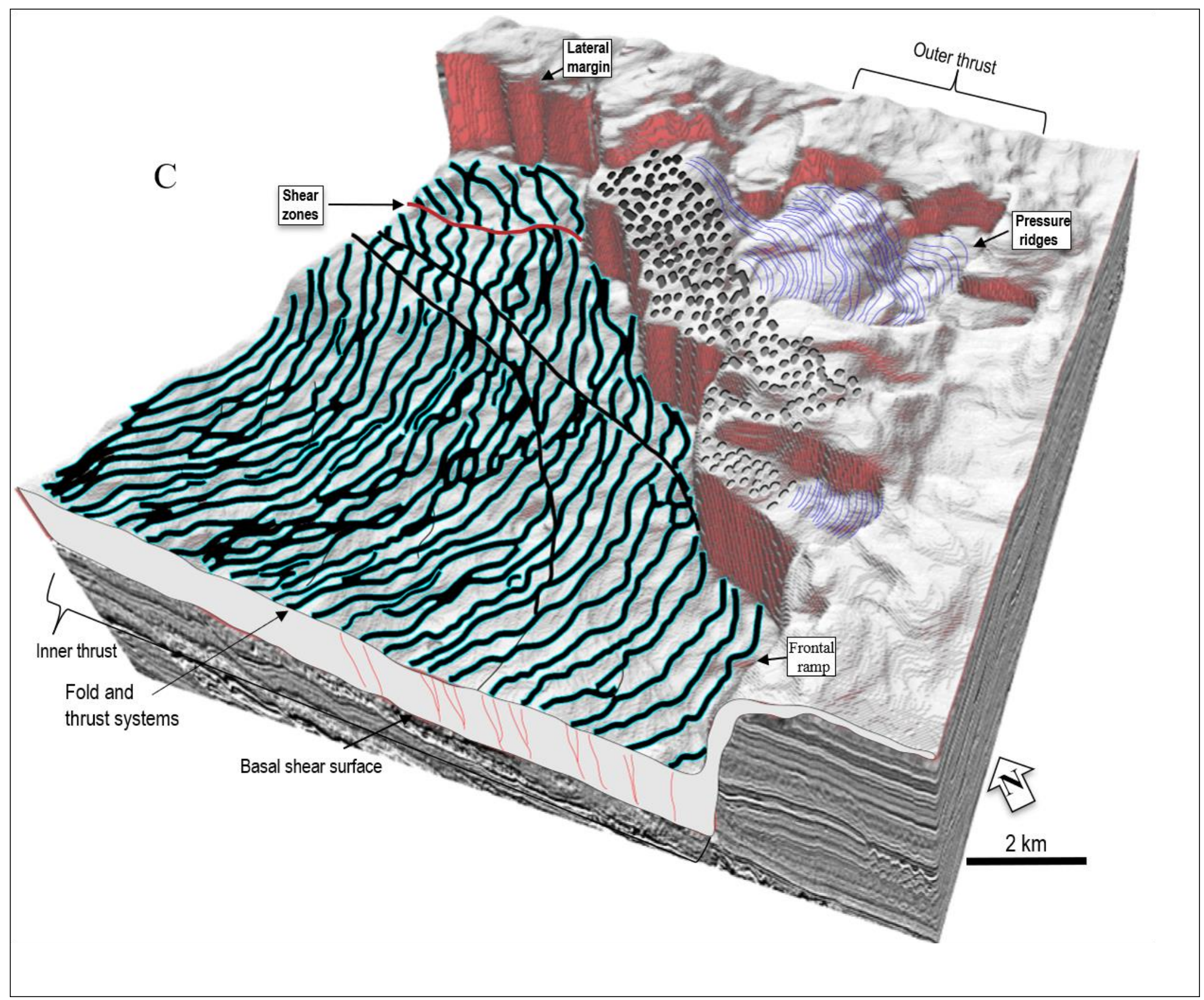




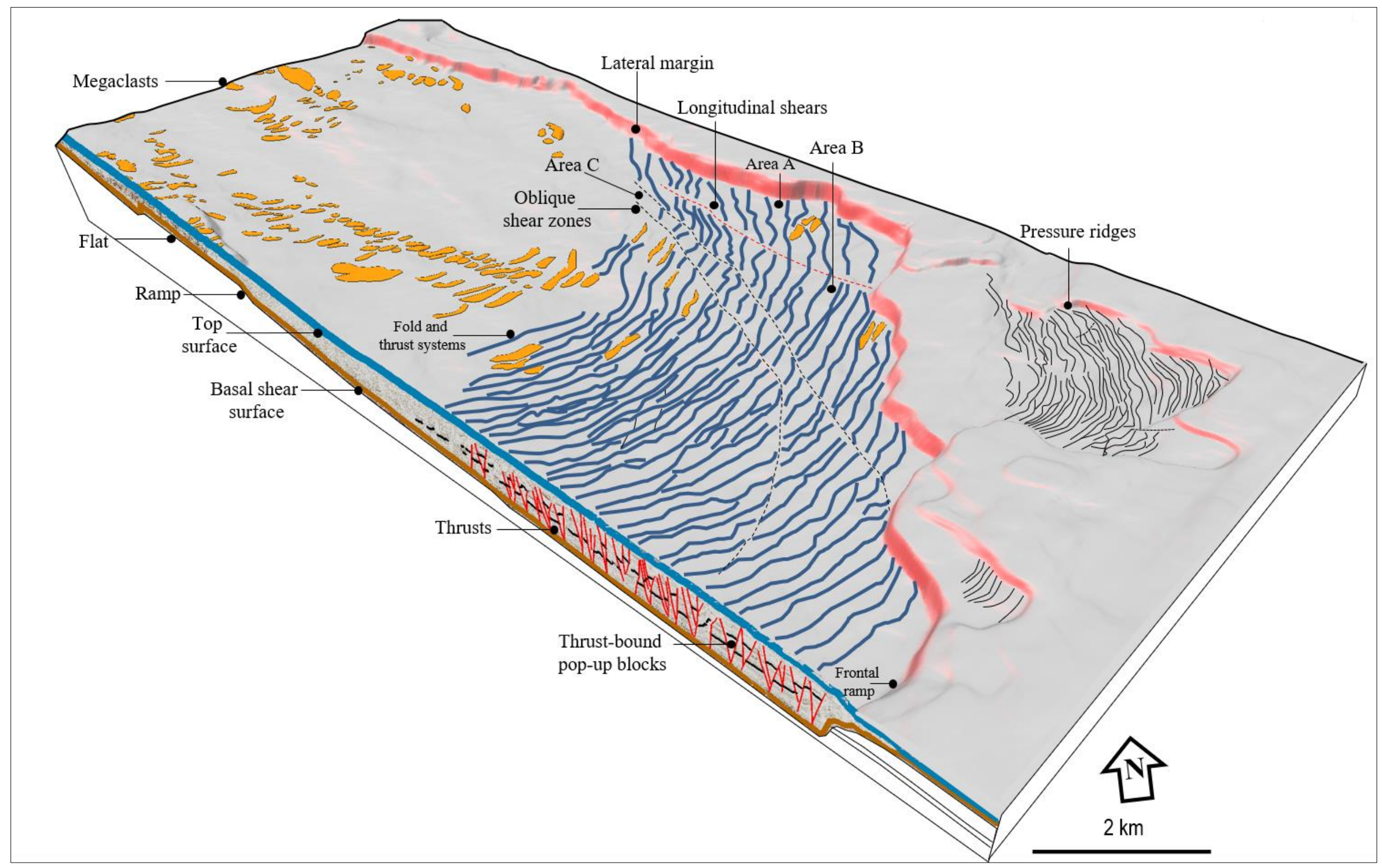

Figure 9 


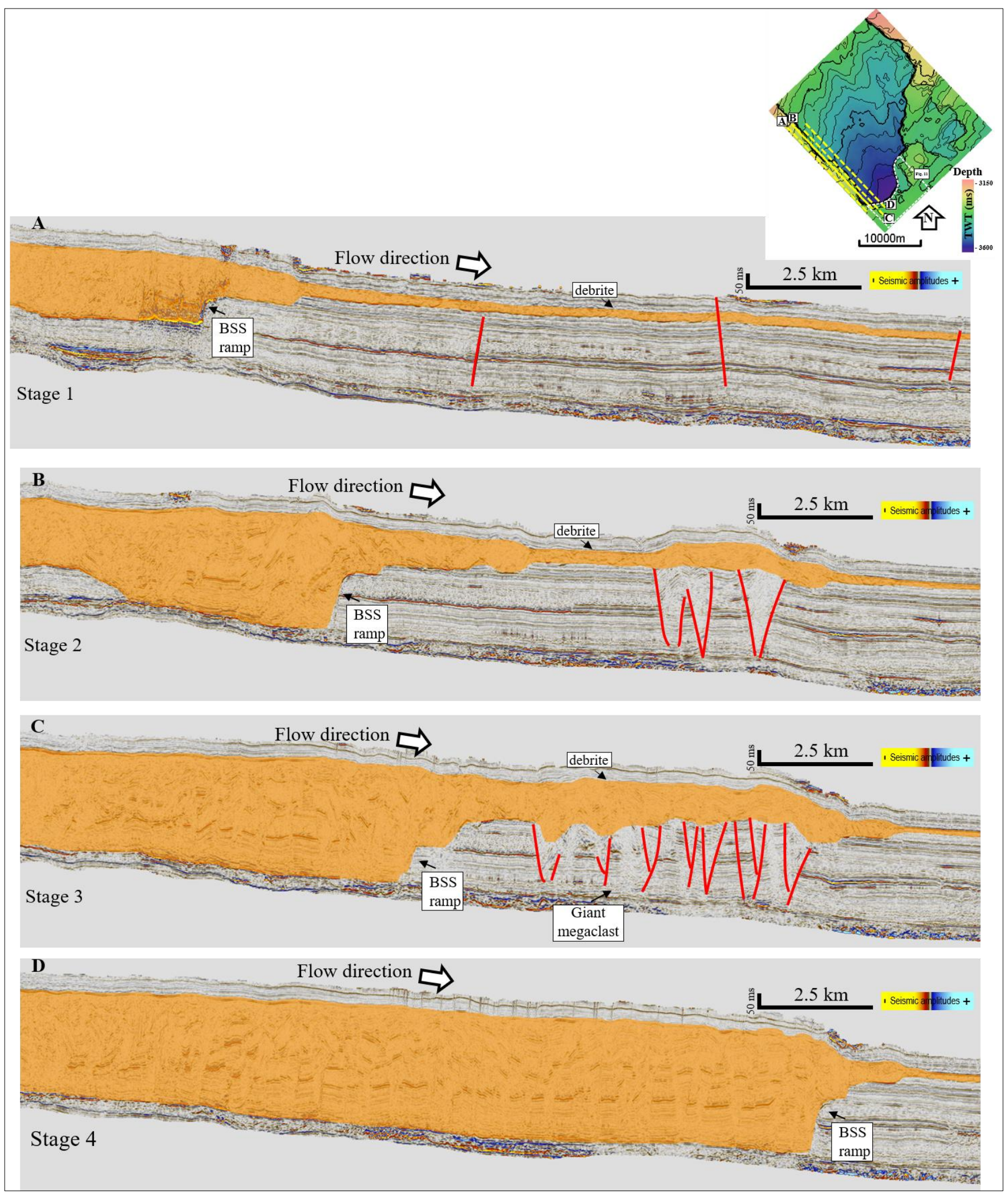

Figure 10 


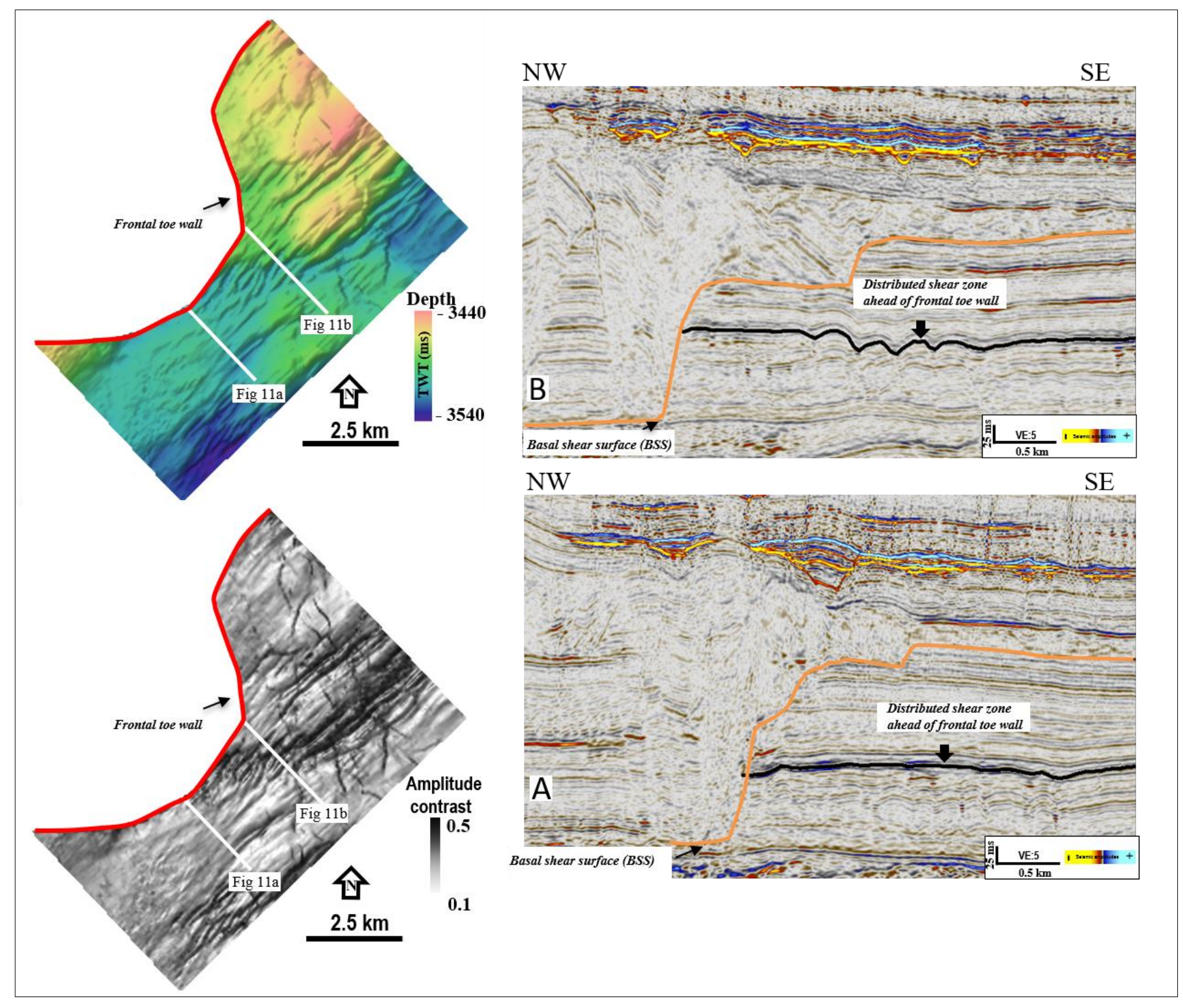

Figure 11 


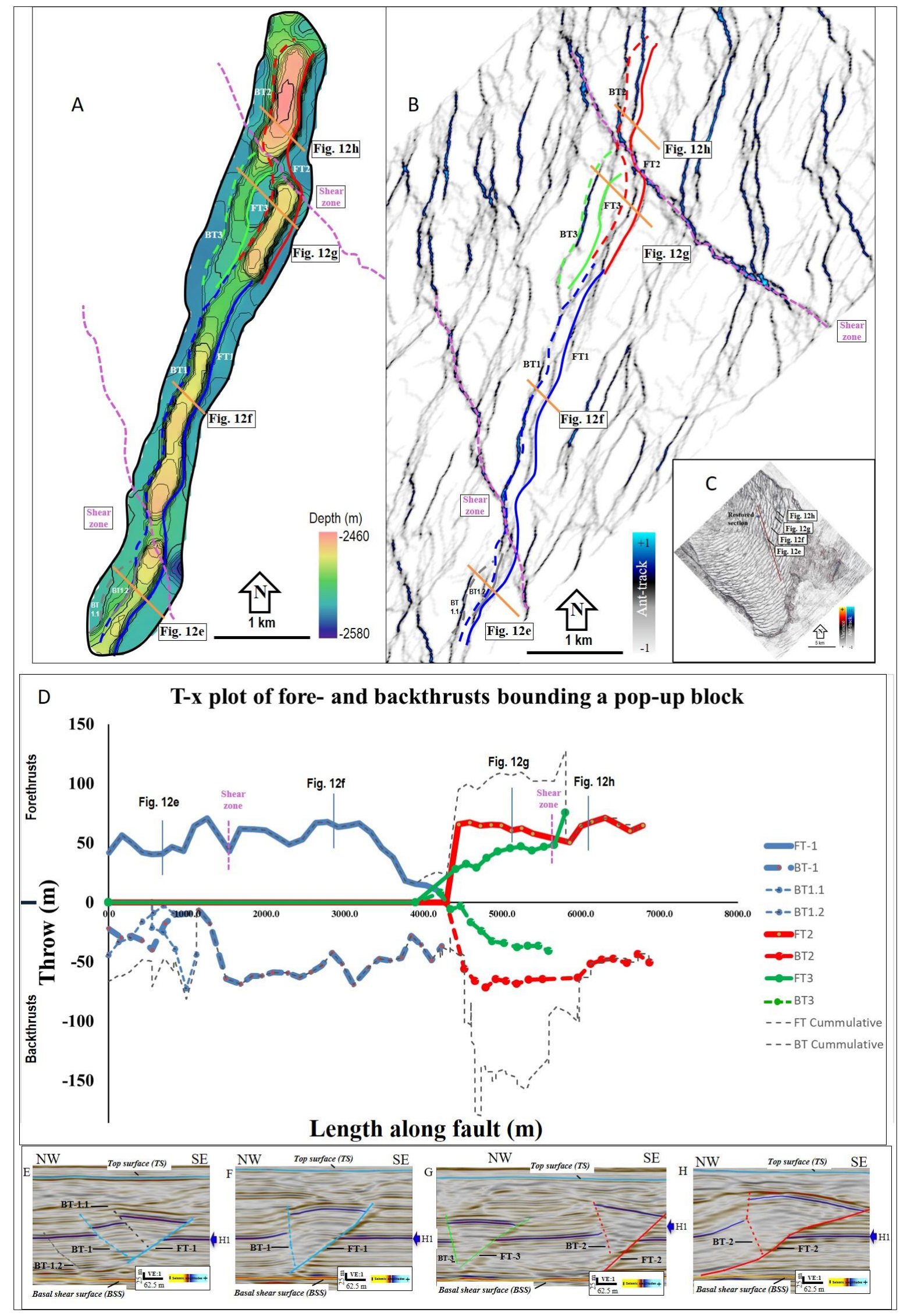

Figure 12 

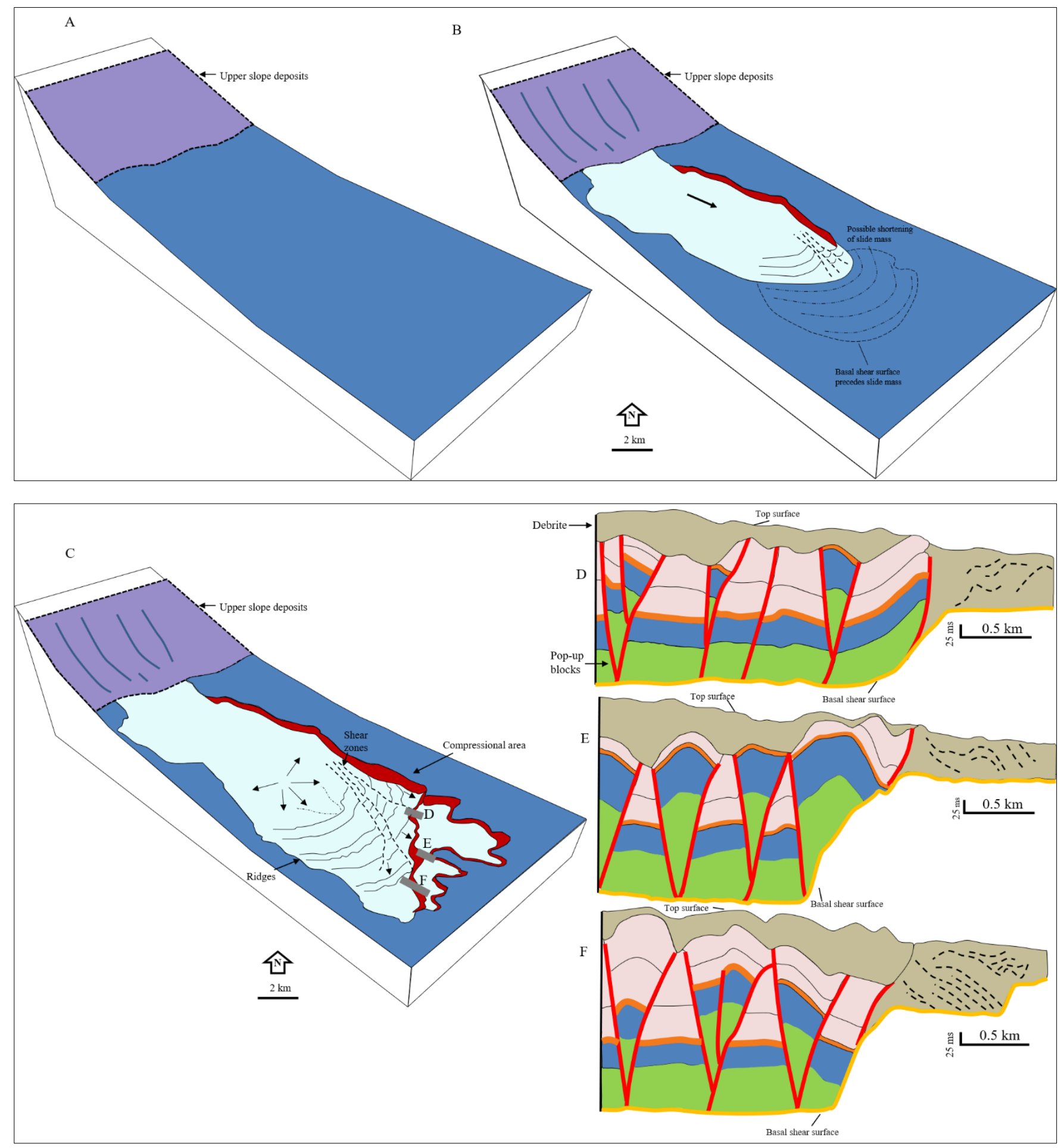

Figure 13 